\title{
EFEITOS DA IMOBILIZAÇÃO E DO EXERCÍCIO FÍSICO EM ALGUMAS PROPRIEDADES MECÂNICAS DO MÚSCULO ESQUELÉTICO
}

\author{
CLAUDIA MATHIAS MARCOS DE CARVALHO
}

\begin{abstract}
Dissertação apresentada à Área de Bioengenharia Interunidades Faculdade de Medicina de Ribeirão Preto/Escola de Engenharia de São Carlos/Instituto de Química de São Carlos, Universidade de São Paulo para obtenção do título de Mestre em Bioengenharia.
\end{abstract}

\section{Orientador: Prof. Dr. José Batista Volpon}

\author{
Ribeirão Preto
}


Ficha catalográfica preparada pela Seção de Tratamento da Informação do Serviço de Biblioteca - EESC-USP

Carvalho, Claudia Mathias Marcos de

Efeitos da imobilização e do exercício físico em algumas propriedades mecânicas do músculo esquelético/

Claudia Mathias Marcos de Carvalho. - São Carlos, 2001.

Dissertação (Mestrado). - Área Interunidades em Bioengenharia da EESC/FMRP/IQSC - Universidade de São Paulo, 2001.

Orientador: Prof. Dr. José B. Volpon

1. Músculo. 2. Imobilização. 3. Rato. 4. Exercícios. 5. Propriedades mecânicas. I. Título. 
Aos meus pais Lourenço e Darcy, meu marido Jairo e meus familiares, pelo apoio e incentivo incondicionais. 



\section{AGRADECIMENTOS}

Ao Prof. Dr. José B. Volpon que dividiu seu tempo e conhecimentos com admirável generosidade.

Ao Dr. Antonio Carlos Shimano pelo exemplo de dedicação e valiosos ensinamentos para a realização deste trabalho e para a vida.

Aos funcionários do Laboratório: Terezinha, Eng. Moro pela amizade e, Francisco Carlos Mazzocato e Luiz Henrique Alves Pereira pela inestimável ajuda durante a fase experimental.

À amiga Eloisa pela amizade incondicional.

Aos amigos Adriano, Luiz Carlos, Valdeci e Vítor pela amizade e pelo auxílio durante a realização desta pesquisa, em especial ao amigo Marcos Shimano pela grande ajuda nos trabalhos de computação.

Aos colegas da pós-graduação pela agradável convivência.

Ao Curso de Fisioterapia da Universidade de Ribeirão Preto pelo incentivo na realização deste trabalho.

À secretária do Laboratório de Bioengenharia da EESC-USP, Janete dos Santos, pela presteza e cordialidade no atendimento aos pós-graduandos.

A todos, meus sinceros agradecimentos! 


\section{SUMÁRIO ${ }^{1}$}

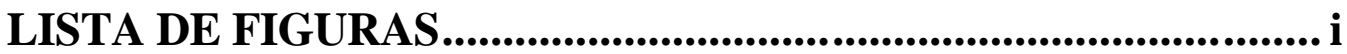

LISTA DE TABELAS .................................................................. ii

LISTA DE ABREVIATURAS E SIGLAS.................................... iii

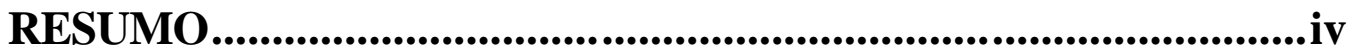

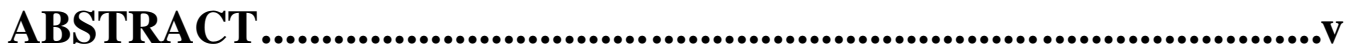

1 INTRODUÇÃO ....................................................................1

1.1 Efeitos da imobilização no músculo esquelético .................................................1

1.2 Efeitos da remobilização no músculo esquelético após período de imobilização......................................................................................................................5

1.3 Ensaio mecânico..............................................................................................................9

1.3.1 Ensaio mecânico de tração.........................................................................10

1.3.2 Ensaio mecânico em tecidos moles .................................................................10

1.4 Objetivo .........................................................................................................................14

2 MATERIAL E MÉTODO .......................................................15

2.1 Animais de experimentação.................................................................................15

2.2 Grupos experimentais .................................................................................. 15

2.3 Caracterização dos grupos................................................................................16

2.3.1 Grupo Controle ………………………………………………………....16

2.3.2 Grupo Imobilizaçã $\tilde{o}$....................................................................................16

2.3.3 Grupo Imobilização - Exercitação...............................................................16

2.3.4 Grupo Imobilização - Liberação ...................................................................17

2.4 Técnica de Imobilização..................................................................................... 17

2.5 Técnica de Exercitação.........................................................................................18

2.6 Coleta de material..................................................................................................20

2.7 Ensaio mecânico de tração....................................................................................21

2.7.1 Propriedades mecânicas................................................................................23

2.7.1.1 Limite de proporcionalidade $(L P)$.............................................24

\footnotetext{
${ }^{1}$ Normas de acordo com as diretrizes para elaboração de dissertações e teses na EESC-USP, $2^{\mathrm{a}}$ ed.
} 


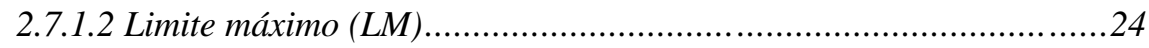

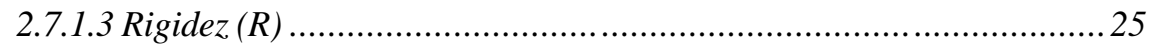

2.7.1.4 Resiliência $\left(E^{\prime}\right)$ - (Energia absorvida na fase elástica $)$....................25

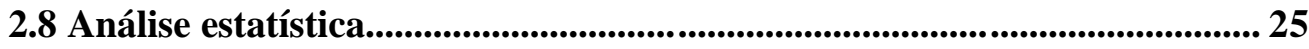

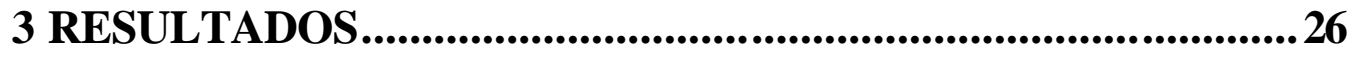

3.1 Curvas carga $x$ deformação ...................................................................................30

3.2 Carga máxima...............................................................................................................34

3.3 Deformação máxima ..............................................................................................35

3.5 Deformação no limite de proporcionalidade ...................................................... 37

3.6 Resiliência.................................................................................................................................. 38

3.7 Rigidez.................................................................................................................................... 39

4 DISCUSSÃO

5 CONCLUSÕES............................................................................48

ANEXOS................................................................................................49

REFERÊNCIAS BIBLIOGRÁFICAS................................................54 


\section{LISTA DE FIGURAS}

FIGURA 01 - Animal com o membro posterior direito imobilizado em aparelho gessado ...17 FIGURA 02 - Reservatório de água montado para realização dos exercícios. Reservatório

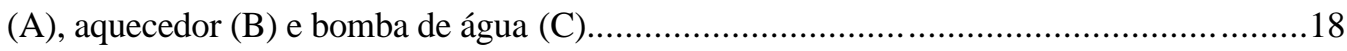

FIGURA 03 - Pesos adaptados à cinta elástica..........................................................19

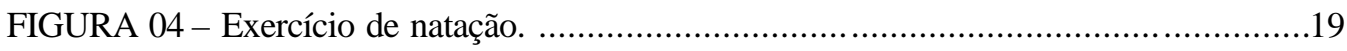

FIGURA 05 - Peça obtida para o ensaio mecânico mostrando o gastrocnêmio, com preservação da origem femoral e inserção no calcâneo.

FIGURA 06 - Montagem para a realização do ensaio de tração axial na máquina universal de ensaios. Célula de carga (A), acessórios para fixação do músculo (B), músculo (C) e relógio comparador (D)

FIGURA 07 - Gráfico carga x deformação, a partir do qual são obtidas as principais propriedades mecânicas do ensaio de tração.

FIGURA 08 - Curvas carga $x$ deformação dos 8 músculos analisados no grupo Controle. ...30 FIGURA 09 - Curvas carga $x$ deformação dos 8 músculos analisados no grupo imobilizados e sacrificados imediatamente após a retirada da imobilização. . .30

FIGURA 10 - Curvas carga $x$ deformação dos 8 músculos analisados no grupo imobilizado e exercitado após a retirada da imobilização.

FIGURA 11 - Curvas carga $x$ deformação dos músculos analisados no grupo imobilizado e não exercitado após a retirada da imobilização.

FIGURA 12 - Comparação entre os valores médios das cargas máximas. . .34

FIGURA 13 - Comparação entre os valores médios das deformações máximas nos diferentes grupos.

FIGURA 14 - Comparação entre os valores médios das cargas proporcionais nos diferentes grupos.

FIGURA 15 - Comparação entre os valores médios das deformações proporcionais nos diferentes grupos.

FIGURA 16 - Comparação entre os valores médios da resiliência e desvio padrão nos diferentes grupos . .38

FIGURA 17 - Comparação entre os valores médios da rigidez e desvio padrão nos diferentes grupos.

FIGURA 18 - Curvas representando as médias das propriedades mecânicas. O primeiro ponto mostra o limite de proporcionalidade e o segundo, o limite máximo para os diferentes grupos experimentais. 


\section{LISTA DE TABELAS}

TABELA 1 - Peso corporal inicial e final. .26

TABELA 02 - Valores médios do peso da peça e do diâmetro do músculo gastrocnêmio ....26

TABELA 03 - Caracterização macroscópica dos músculos gatrocnêmios nos grupos

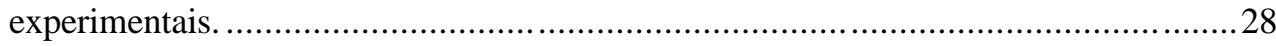

TABELA 04 - Local de ruptura dos músculos gastrocnêmio durante o ensaio mecânico, nos diferentes grupos. .29

TABELA 05 - Valores das propriedades mecânicas dos músculos dos animais do grupo Controle. 32

TABELA 06 - Valores das propriedades mecânicas dos músculos dos animais do grupo Imobilização. .32

TABELA 07 - Valores das propriedades mecânicas dos músculos dos animais do grupo Imobilização-Exercitação.

TABELA 08 - Valores das propriedades mecânicas dos músculos dos animais do grupo Imobilização-Liberação. .33 


\section{LISTA DE ABREVIATURAS E SIGLAS}

\begin{tabular}{|c|c|}
\hline$\theta$ & - ângulo de inclinação da curva carga $x$ deformação na fase elástica \\
\hline $\mathrm{ABNT}$ & - Associação Brasileira de Normas Técnicas \\
\hline $\mathrm{cm}$ & - centímetro \\
\hline CPM & - Continuous Passive Mobilization \\
\hline$E^{\prime}$ & - energia absorvida pelo material na fase elástica (resiliência) \\
\hline $\mathrm{g}$ & - grama \\
\hline $\mathrm{Hz}$ & - Hertz \\
\hline $\mathrm{J}$ & - Joule \\
\hline kgf & - quilograma força \\
\hline $\mathrm{m}$ & - metro \\
\hline $\mathrm{mm}$ & - milímetro \\
\hline $\mathrm{N}$ & - Newton \\
\hline NASA & - National Aeronautics and Space Administration \\
\hline PVC & - polivinil cloreto \\
\hline $\mathrm{R}$ & - rigidez \\
\hline $\operatorname{Tg}$ & - tangente \\
\hline
\end{tabular}




\section{RESUMO}

CARVALHO, C.M.M. (2001). Efeitos da imobilização e do exercício físico em algumas propriedades mecânicas do músculo esquelético. Ribeirão Preto, 2001. 59p. Dissertação (Mestrado) - Escola de Engenharia de São Carlos/Faculdade de Medicina de Ribeirão Preto/ Instituto de Química de São Carlos, Universidade de São Paulo.

Foi estudada a influência da imobilização, remobilização livre e remobilização com treinamento físico sobre as propriedades mecânicas do músculo esquelético. O limite máximo, limite proporcional, rigidez e resiliência foram obtidos a partir de ensaio de tração axial. Foram utilizados os músculos gastrocnêmio de 37 ratas fêmeas albinas, da variedade Wistar, divididas em 4 grupos. Um grupo foi utilizado como controle. Três grupos tiveram o membro posterior direito imobilizado com aparelho de gesso por três semanas. Destes, um grupo foi sacrificado logo após a retirada da imobilização, outro foi submetido a período de remobilização livre e o terceiro à remobilização com treinamento físico com natação por quatro semanas. Houve redução estatisticamente significante para os valores das propriedades mecânicas para os músculos submetidos à imobilização. A remobilização constituída por exercitação não produziu a recuperação da resiliência. Houve aumento estatisticamente significante da rigidez para os músculos submetidos ao treinamento físico.

A remobilização livre devolveu ao músculo suas propriedades mecânicas.

Palavras -chave: músculo, imobilização, rato, exercícios, propriedades mecânicas. 


\begin{abstract}
CARVALHO, C.M.M. (2001). Effects of immobilization and physical training on the mechanical properties of the striated muscle. Ribeirão Preto, 2001. 59p. Dissertação (Mestrado) - Escola de Engenharia de São Carlos/Faculdade de Medicina de Ribeirão Preto/ Instituto de Química de São Carlos, Universidade de São Paulo.
\end{abstract}

The influence of immobilization, free remobilization and remobilization followed by physical training on the mechanical properties of the striated muscle was studied in rats. The right gastrocnemius was tested in traction and the following mechanical parameters were obtained: ultimate limit, elastic limit, stiffness and resilience. Thirty-seven adult female Wistar rats were used and divided in four groups. One group was kept as a control and consisted of non-immobilized animals. In the three other groups the right hind limb was immobilized in a spica cast during three weeks. In the last group the animals were exercised with swimming after the immobilization period, during four weeks. Our results showed that there was a remarkable decrease of mechanical parameters with the immobilization. In the group with immobilization followed by exercise there was not recovery for the resilience. All trained animals showed a statistically significant recovery of the stiffness. With the mobilization the muscle recovered the normal parameters.

Key-words: muscle, immobilization, rat, exercise, mechanical properties. 


\section{INTRODUÇÃO}

As fraturas ósseas, rupturas ligamentares, lesões musculares, como também doenças degenerativas ou articulares, podem exigir, após cirurgia ou tratamento conservador, imobilização dos membros, que é comumente realizada por meio da aplicação de ataduras gessadas (APPELL, 1986a).

O músculo é o elemento motor do corpo humano, acionando voluntária ou involuntariamente os segmentos corpóreos. A musculatura estriada, de contração voluntária, é denominada musculatura esquelética (JUNQUEIRA \& CARNEIRO, 1999).

A função do músculo esquelético depende de atividade proprioceptiva intacta, inervação motora, carga mecânica e mobilidade articular. O músculo é o mais mutável dentre os tecidos biológicos e responde a demandas normais ou alteradas com adaptações morfológicas e funcionais (APPELL, 1986a; ROSE \& ROTHSTEIN, 1982; LIEBER, 1992; SILVEIRA et al., 1994).

Estes achados têm implicações extremamente importantes para os fisioterapeutas. $\mathrm{O}$ conhecimento e o entendimento dessas adaptações permitem que o fisioterapeuta seja mais efetivo em avaliação e tratamento, compreendendo os efeitos fisiológicos da intervenção imposta e, respondendo melhor às necessidades individuais do paciente (ROSE \& ROTHSTEIN, 1982).

\subsection{Efeitos da imobilização no músculo esquelético}

Vários modelos experimentais foram feitos para determinar as mudanças que ocorrem no músculo após um período de imobilização.

Historicamente, técnicas invasivas como desnervação, tenotomia e fixação da articulação por meio de pinos, forneceram a base para o conhecimento das alterações 
provocadas pela imobilização. Desnervação é alcançada por meio de secção ou esmagamento nervoso, ou ainda por bloqueio químico, eliminando a comunicação do músculo com o nervo, impedindo a ocorrência de reflexos musculares. Na tenotomia, a conexão músculo-osso é interrompida, ocasionando um encurtamento artificial do músculo. Os resultados, porém, não podem ser comparados com as alterações provocadas por imobilização (APPELL, 1986a e MUSACCHIA, 1988).

Os efeitos da imobilização por meio de técnicas não invasivas, como, imobilização por aparelho gessado ou suspensão do corpo, têm sido estudadas com mais frequiência. Esta expansão nos estudos para as técnicas não invasivas tem sido ajudada pela NASA (National Aeronautics and Space Administration), que busca determinar os mecanismos da atrofia muscular e como conter esta atrofia, que acontece ao indivíduo exposto à uma microgravidade, tentando simular as condições de um vôo espacial (MUSACCHIA, 1988).

A maioria dos experimentos para se estudar os eventos que ocorrem no músculo durante e após a imobilização, foi realizada em animais, devido principalmente a questões éticas. Investigações em humanos, voluntários ou pacientes, poderiam fornecer somente medidas de trofismo muscular, força de um grupo de músculos, características de contração e, talvez, alguns parâmetros morfológicos e bioquímicos obtidos por meio de biopsia muscular (APPELL, 1990).

Os modelos animais permitem maior compreensão das alterações provocadas no músculo pela imobilização. MUSACCHIA (1988), em uma revisão sobre atrofia muscular por desuso, comparou os diferentes modelos animais e sua influência em relação aos aspectos morfológicos, fisiológicos, bioquímicos e de força do músculo. Em todos os experimentos, a principal característica observada foi a atrofia muscular e diminuição da atividade contrátil do músculo. MUSACCHIA verificou, também, que a atrofia muscular é um processo complexo e diferenças significativas são associadas com os resultados das técnicas utilizadas para provocar o desuso. 
Em um estudo sobre atrofia muscular, THOMPSON (1934) imobilizou, com aparelho gessado, um membro posterior de um grupo de coelhos, em posição flexionada, naturalmente adquirida pelo animal, e, permitindo descarga de peso. Em um outro grupo, manteve a imobilização com os membros em posição estendida, não permitindo o apoio. Sacrificou um animal de cada grupo a cada semana, durante seis semanas, e analisou as características dos músculos da panturrilha e isquiotibiais. Ficou evidenciado que a imobilização provocou uma grande atrofia muscular, porém ela foi menor nos animais onde foi permitida a descarga de peso. Esse autor constatou, ainda, que, nas condições do experimento, os músculos da panturrilha atrofiaram mais que os isquiotibiais. Encontrou várias dificuldades na execução do modelo de imobilização utilizado no experimento, como, alterações na circulação venosa, edema do membro imobilizado e ulcerações provocadas pelo atrito do membro com o aparelho gessado.

BOOTH \& KELSO (1973) descreveram um método de imobilização para quadril, joelho e tornozelo de ambos os membros posteriores de ratos, não encontrando as dificuldades descritas por THOMPSON (1934). Os autores analisaram as alterações no músculo por meio da observação macroscópica e do peso do músculo, constatando diferença significativa para os imobilizados, em relação aos controles. A ausência de úlceras gástricas, ulceração da pele, edema, bem como a produção de atrofia muscular, indicou a aceitabilidade do modelo para estudos sobre o desuso do músculo.

BOOTH (1977) imobilizou membros posteriores de ratos com aparelho gessado, durante períodos variados. Analisou a quantidade de proteínas no músculo e a atrofia muscular. Constatou que o nível de proteínas diminuía consideravelmente após 4-6 dias de imobilização. Em contraste, a quantidade de mioglobina permaneceu inalterada. Quando o membro foi imobilizado em posição encurtada, a atrofia ocorreu mais tardiamente.

HERBISON, JAWEED \& DITUNNO (1978), com o propósito de avaliar os efeitos da imobilização nos músculos flexores plantares de ratos, utilizaram o modelo proposto por BOOTH \& KELSO (1973). A imobilização foi mantida por 6 semanas. Os músculos foram 
avaliados em relação ao peso, conteúdo de proteínas e propriedades histoquímicas. Esses autores encontraram que existiu perda de peso em todos os músculos: gastrocnêmio, sóleo e plantar, e, ainda diminuição das proteínas. A atrofia de fibras musculares tipo I e II foi igual no músculo sóleo e a do tipo II foi maior que o tipo I para o músculo plantar, sugerindo que o grau de atrofia seja específico para o tipo de fibra e sua localização no músculo ou músculos diferentes.

FOURNIER et al. (1983), com o intuito de entender melhor os efeitos da imobilização sobre os músculos fixados em várias posições, realizaram experimentos em ratos, que tiveram os membros posteriores imobilizados. Os músculos sóleo e gastrocnêmio foram colocados em posição encurtada, neutra ou alongada. Os resultados mostraram que os músculos imobilizados em posição encurtada diminuíram significativamente o peso, após 28 dias de imobilização, mas isto não aconteceu para o imobilizado em posição alongada. Após imobilização em posição encurtada, a atividade eletromiográfica dos músculos sóleo e gastrocnêmio foi reduzida significativamente para $77 \%$ e $50 \%$ respectivamente, comparadas ao controle. A atividade eletromiográfica do músculo sóleo, imobilizado em posição neutra, diminuiu 50\%, considerando que nenhuma mudança foi observada para o gastrocnêmio. Não existiu mudança significativa para o sóleo ou para o gastrocnêmio imobilizados em posição alongada. Os dados sugeriram que o resultado do eletromiograma é dependente do tipo de músculo e da posição de imobilização do músculo.

JÄRVINEN et al. (1992) compararam as propriedades elásticas da unidade músculo tendão de gastrocnêmio de ratos que tiveram seu membro posterior esquerdo imobilizados com aparelho gessado, mantendo o joelho em flexão e o tornozelo em extensão, ou viceversa. Utilizaram o membro contralateral como controle. Após 7 a 21 dias de imobilização, analisaram as curvas carga $x$ deformação e o peso das unidades músculo-tendíneas do gastrocnêmio de cada rato. A redução na rigidez foi semelhante em ambos grupos. A perda de capacidade de absorção de energia foi mais pronunciada nos músculos imobilizados em posição encurtada (64\%) que em músculos imobilizados em posição alongada (49\%). A 
perda de peso foi maior nos imobilizados em posição encurtada. Concluíram que a imobilização da unidade músculo-tendão do gastrocnêmio de rato imobilizada em posição encurtada é seguida por atrofia mais acentuada e uma diminuição nas propriedades elásticas que a imobilizada em posição alongada.

Os estudos onde os animais são mantidos em suspensão ou hipocinesia, têm sido executados tentando simular as condições que acontecem em vôos espaciais. Embora o método produza condições diferentes da imobilização (os animais podem realizar contrações dinâmicas, porém com carga mínima), os efeitos provocados no músculo são semelhantes aos produzidos pela imobilização com gesso ou fixações articulares com pinos metálicos (FITTS et a1., 1986).

Todos esses estudos que tiveram por objetivo entender o mecanismo de desenvolvimento e adaptação do músculo esquelético à imobilização, permitiram algumas importantes observações que são enfatizadas por SALVINI (2000): o músculo adapta-se às alterações em seu comprimento; a posição (encurtada ou alongada) em que o músculo é mantido é fator determinante nas alterações estruturais; o grau de atrofia muscular durante a imobilização depende da posição de imobilização, e é maior no grupo encurtado; a perda de força acontece como uma característica funcional da atrofia.

\subsection{Efeitos da remobilização no músculo esquelético após período de}

\section{imobilização}

As forças físicas fornecem estímulos importantes para a manutenção da homeostase e desenvolvimento dos tecidos.

O advento da movimentação passiva contínua (CPM - Continuous Passive Mobilization) na década de 1970 e início dos anos 80, forneceu o estímulo necessário para se iniciar precocemente o movimento e também a estimulação elétrica do músculo para 
favorecer a regeneração dos tecidos, diminuição da atrofia muscular e promoção da reeducação muscular, após cirurgias ou reconstruções ligamentares e articulares (HARRELSON,1998).

Porém, a imobilização com a aplicação de gesso é amplamente utilizada no tratamento de muitas reconstruções ligamentares, fraturas ou traumas. Segundo HARRELSON (1998), não é conhecido se todos os efeitos lesivos de uma imobilização prolongada sobre os tecidos podem ser totalmente revertidos com técnicas de remobilização.

É conhecido que o músculo responde à remobilização mais rapidamente que outras estruturas de tecido conjuntivo. A recuperação do músculo começa dentro de três a cinco dias após o início de um programa de exercícios. (COOPER, 1972 e ZARINS, 1982 apud HARRELSON, 1998) $)^{2}$

Programas de treinamento com exercícios, após períodos de imobilização, são estabelecidos com freqüência.

Comparados com os efeitos do treinamento físico ou da imobilização, estudos sobre os efeitos da remobilização sobre os tecidos músculo-esqueléticos são pouco realizados e o conhecimento verdadeiro nesse assunto também é escasso. $O$ que se sabe é que, a recuperação de qualquer componente dos tecidos músculo-esqueléticos, exige muito mais tempo que o necessário para causar atrofia após imobilização (KANNUS et al.,1997).

BOOTH (1978), em trabalho experimental com ratos, avaliou a recuperação do trofismo muscular após vinte e oito dias de imobilização com aparelho gessado. Foi medida a quantidade total de proteínas para os músculos sóleo e gastrocnêmio. Observou que não houve alteração na quantidade de proteínas durante os três primeiros dias após a remoção da imobilização. O aumento da quantidade de proteínas ocorreu mais significativamente no décimo sexto dia, progredindo até o qüinquagésimo dia para o músculo gastrocnêmio,

\footnotetext{
${ }^{2}$ ZARINS, B. (1982). Soft tissue injury and repair: biomechanical aspects Int Journal Sports Med, v.3, p19-25.
} 
enquanto que os valores encontrados para o músculo sóleo não foram significativamente diferentes do controle durante a recuperação. O peso muscular para o músculo gastrocnêmio foi recuperado após o quinqüagésimo dia de recuperação. O peso do músculo sóleo foi rapidamente restabelecido após a retirada da imobilização, não sendo consideradas significantes as diferenças em relação ao controle. BOOTH atribuiu os resultados aos diferentes tipos de fibras que constituem os dois músculos.

Resultados semelhantes foram encontrados por BOOTH \& SEIDER (1979). Os autores mostraram que as propriedades bioquímicas e fisiológicas do músculo esquelético são recuperadas em períodos de tempo variados, após o término da imobilização.

APPELL (1986b) analisou os efeitos da imobilização e de um programa de exercícios pré e pós-imobilização, sob aspectos morfológicos no músculo esquelético. Para o estudo, imobilizou membros posteriores de ratos com aparelho gessado, por períodos diferentes de tempo. Verificou a atrofia do músculo tibial anterior medindo cortes transversais do músculo.

Em uma segunda série de experiências, exercitou os ratos em uma esteira, por um período de sete dias antes e depois da imobilização, e um dos grupos exercitou somente depois da imobilização. A diminuição no diâmetro das fibras musculares foi mais evidente durante a primeira semana de imobilização. As alterações estruturais observadas foram perda e fragmentação de miofibrilas e mitocôndrias, que também apresentaram capacidade regenerativa. Os efeitos do treinamento pós-imobilização foram documentados por um aumento no diâmetro das fibras musculares. Os músculos que foram treinados antes da imobilização tiveram atrofia muscular considerada desprezível. Como as alterações estruturais nos músculos somente imobilizados foram graves, APPELL concluiu que o programa de treinamento pós-imobilização deve ser empreendido com cuidado.

Com o intuito de investigar quanto tempo o músculo leva para recuperar o trofismo perdido com imobilização, LIEBER et al. (1989) realizaram um estudo com cães, que tiveram o músculo quadríceps imobilizado por meio de fixação externa esquelética do 
joelho, por dez semanas, seguidas por quatro semanas de remobilização. Durante as quatro semanas de remobilização, foi permitido atividade normal e, ainda, estimulada a caminhada ou a corrida durante uma hora por dia. Observaram que, mesmo após o período de remobilização, havia diminuição de aproximadamente $30 \%$ nas áreas de fibras musculares de contração lenta e rápida. A quantidade de tecido conjuntivo extracelular aumentou durante o período de imobilização, enquanto que nenhuma diferença foi vista entre os músculos controle e os remobilizados. Os autores presumiram que a remobilização devolve o músculo a seu nível normal de funcionamento.

JÄRVINEN (1993) estudou em rato os efeitos da imobilização e mobilização precoce no processo de cicatrização do músculo gastrocnêmio com ruptura parcial. Observou que a imobilização após à lesão limita a extensão da área de tecido conjuntivo formado no local da lesão. Neste local ocorria a penetração de fibras musculares através do tecido conjuntivo, porém a orientação das fibras era complexa e não paralela, como no músculo normal. A mobilização logo após a lesão foi seguida pela formação de uma densa cicatriz conjuntiva no local, impedindo a regeneração do músculo. Quando a mobilização inicioutse, após um pequeno período de imobilização, ocorreu uma melhor penetração das fibras musculares através do tecido conjuntivo, e, as novas fibras musculares estavam alinhadas como as fibras de músculo normal. JÄRVINEN concluiu que, embora seja necessário um pouco mais de tempo para a recuperação, um curto tempo de imobilização, seguido de mobilização, proporciona uma melhor qualidade na regeneração muscular após lesão.

KANNUS et al. (1998), com o propósito de investigar se seria possível a recuperação completa do tecido muscular após imobilização e, quais os melhores métodos para uma recuperação mais favorável, analisaram os efeitos de três semanas de imobilização seguidas de atividade livre na gaiola, e exercícios de alta e baixa intensidade em uma esteira, durante oito semanas. Para tanto avaliaram o comportamento dos músculos sóleo e gastrocnêmio de ratos submetidos às diferentes condições. Observaram alterações morfológicas e histoquímicas significantes após a imobilização. Muitas mudanças não foram 
revertidas completamente com a livre remobilização. Com o treinamento físico houve melhor restabelecimento do músculo. Os autores concluíram que as alterações patológicas induzidas pela imobilização são fenômenos, em grande parte, reversíveis, se a remobilização for intensificada por treinamento físico, parecendo ser mais benéfico o exercício de alta intensidade.

ZARZHEVSKY et al. (1999), utilizando fixação externa do joelho, imobilizaram o membro posterior de ratos durante quatro semanas. O membro oposto serviu como controle. Para um grupo, foram permitidas quatro semanas de remobilização com atividade normal após a retirada da fixação. A imobilização causou redução de aproximadamente 50\% no peso dos músculos gastrocnêmio, quadríceps, sóleo e plantar. Os valores não foram completamente restabelecidos após a remobilização. Os valores para a creatinofosfoquinase foram reduzidos em $40 \%$ com a imobilização, retornando aos valores quase normais ao término do período de remobilização. $\mathrm{O}$ exame histológico e ultraestrutural do músculo gastrocnêmio mostrou acentuada miopatia após a imobilização, o que foi revertido após a remobilização. Concluíram que, após quatro semanas de remobilização, os músculos não retornam aos seus pesos pré-imobilização, embora a morfologia seja restabelecida, sustentando os resultados de MAEDA et al. (1993).

\subsection{Ensaio mecânico}

A Engenharia Biomédica abrange vasto campo científico e multidisciplinar, beneficiando toda a Medicina e a Reabilitação, em suas várias interfaces (RAMOS, 1979).

O conhecimento das características de resistência de alguns materiais é importante na medicina ortopédica e esportiva. Materiais biológicos tais como músculo, osso, ligamentos, tendões e cartilagem, muitas vezes, necessitam de otimização de sua resistência para evitar a ruptura (GOULD, 1993). A Engenharia colabora na avaliação das propriedades 
mecânicas dos tecidos componentes do corpo humano ou dos materiais que são utilizados para substituir ou reparar alguma parte dele. Para estudar o comportamento dos materiais ou tecidos quando submetidos a esforços, utilizam-se os chamados ensaios mecânicos que podem ser de: tração, torção, compressão, entre outros.

\subsubsection{Ensaio mecânico de tração}

O ensaio mecânico de tração é o mais importante de todos os ensaios citados devido à facilidade de execução e reprodutividade dos resultados. Consiste em submeter um material a um esforço que tende a alongálo (SOUZA,1974).

O material é fixado em uma máquina de ensaio que aplica esforços crescentes na direção axial longitudinal. As deformações correspondentes são medidas por uma ponte de extensometria. As deformações promovidas no material são uniformemente distribuídas em todo o corpo. Devido à possibilidade de fazer com que a carga cresça lentamente durante o teste, o ensaio de tração permite medir satisfatoriamente a resistência do material (SOUZA, 1974). Para que os resultados obtidos sejam confiáveis, é preciso que o ensaio seja realizado com determinadas normas e padronizações (CHIAVERINI, 1977).

\subsubsection{Ensaio mecânico em tecidos moles}

MACMASTER (1933) testou o complexo calcâneo - tendão calcâneo - músculo gastrocnêmio - fêmur de coelhos adultos afim de determinar a resistência à tração. Ficou demonstrado que o tendão normal não se rompe mesmo quando sujeito à grande tensão. Houve rompimento do ventre muscular, na junção músculo-tendínea, na origem ou inserção do músculo ou ainda, fratura com avulsão óssea. Para rompimento do tendão a uma grande tensão, metade de suas fibras já deveriam estar rompidas; para romper com uma tensão moderada, aproximadamente 3/4 das fibras já deveriam estar rompidas. 
CARAZZATO et al. (1980) realizaram estudos experimentais em ratos e descreveram as alterações histológicas e mecânicas induzidas pela infiltração de corticóide e anestésico. No primeiro, ocorreu diminuição significante na resistência tecidual, 24 horas após a aplicação do corticóide. A infiltração local com xilocaína não provocou alteração na resistência mecânica.

WOO et al. (1982) estudaram a relação da imobilização e do exercício na remodelação dos tecidos, avaliando as propriedades mecânicas em ensaios de tração. Um estudo do lig amento colateral do joelho em ratos que tiveram seu joelho imobilizado por 9 semanas mostrou que existia uma redução de aproximadamente um terço dos valores relativos à rigidez, carga máxima e energia absorvida comparados ao membro colateral.

Os mesmos autores, em outro estudo, submeteram porcos anões a um programa de exercícios em esteira com duração de 3 e 12 meses e comparados a grupos não exercitados. Concluíram que um prazo curto de exercícios tinha efeito mínimo nas propriedades mecânicas do tendão extensor digital, porém um prazo longo de exercícios tem efeitos positivos para as mesmas propriedades no sentido de aumentá-las. Nos tendões flexores não foram observadas alterações significativas.

CARAZZATO et al. (1985) estudaram experimentalmente a resistência muscular do músculo gastrocnêmio em condições normais e sob fadiga, utilizando ensaios de tração. Concluíram haver menos resistência do músculo à tração quando este é levado à fadiga por estimulação elétrica, em relação ao controle.

BINKLEY et al. (1986) submeteram ligamento colateral de ratos a ensaios de tração após 40 dias de imobilização do joelho com pino intra e extra-articular. Observaram redução significativa na tensão linear, tensão máxima e rigidez para os ligamentos imobilizados, quando comparados ao contralateral, utilizado como controle. Atribuíram os achados à diminuição da síntese e à maior degradação do colágeno, observadas em estudos histológicos e histoquímicos. 
GARRET et al. (1987) compararam as propriedades mecânicas de músculos de coelhos não estimulados e estimulados eletricamente. As comparações foram feitas entre: 1) músculos estimulados com $64 \mathrm{~Hz}$ (estimulação tetânica), 2) músculos estimulados com $16 \mathrm{~Hz}$ (com somatória de onda) e 3) músculos estimulados com $64 \mathrm{~Hz}$ e $16 \mathrm{~Hz}$, com músculos não estimulados. Os músculos estimulados tetanicamente e por somatória de onda exigiram uma maior força para que fossem rompidos, em relação os controles. Não houve diferença significativa para os músculos estimulados com $16 \mathrm{~Hz}$ e $64 \mathrm{~Hz}$.

ROSSI et al. (1990), em estudo de 20 joelhos de cadáveres frescos, por meio de ensaio de tração, determinaram não haver proporcionalidade entre as características mecânicas do ligamento cruzado anterior e do terço central do tendão patelar, e que a resistência das estruturas estudadas não se altera com a idade.

TAYLOR et al. (1990), desenvolveram um modelo experimental para avaliar clinicamente a relevância das propriedades mecânicas em uma unidade músculo-tendínea com o objetivo de caracterizar o comportamento viscoelástico e as aplicações clínicas desta propriedade. Os músculos extensor digital longo e tibial anterior foram submetidos a diferentes taxas de alongamento. Foi verificado que a unidade músculo-tendão responde viscoelasticamente para cargas aplicadas dentro da fase elástica. Os grupos submetidos a estiramento estático e cíclicos apresentaram flexibilidade maior que a encontrada nos que sofreram estiramento rápido.

SALOMÃO et al. (1994) estudaram o comportamento mecânico do tendão tibial posterior em 14 pares de tornozelo de homens e mulheres. Os tendões foram submetidos a ensaios mecânicos de tração axial. Os resultados foram analisados quanto à faixa etária, sexo e lado. Mulheres acima de 50 anos apresentavam resistência à tração significativamente inferior em relação aos homens da mesma faixa etária. Não houve diferença significante na resistência máxima entre os lados direito e esquerdo, que também, não se alterou com a idade entre os homens. 
SELL et al. (1996) realizaram estudo ultra-sonográfico, histológico e mecânico em 34 tendões do calcâneo de cadáveres. Os tendões foram previamente examinados por meio de ultra-sonografia e, depois, submetidos a ensaio mecânico de tração e avaliação histológica. As propriedades mecânicas foram maiores para os tendões onde não havia sido encontrada alteração no estudo sonográfico. O tendão rompia-se, geralmente, onde havia sido encontrada alguma alteração. Quando existiam diferenças de mais de $25 \%$ na resistência à tração para tendão direito e esquerdo, foi observada mudança histológica no tendão mais fraco no local da ruptura. Os autores concluíram que a ultra-sonografia pode ser um método útil na descoberta de lesões degenerativas de tendões.

MÜLLER (1998), com o objetivo de comparar as propriedades mecânicas do ligamento patelar e do tendão calcâneo, realizou ensaios mecânicos de tração em material obtido de cadáveres. Concluiu que ambos possuem carga máxima, limite de proporcionalidade e tensão semelhantes. O módulo de elasticidade foi significativamente maior no ligamento da patela. Esta variável foi a que melhor caracterizou a diferença de comportamento dos dois materiais.

MENEZES et al. (1999) analisaram os efeitos da aplicação do ultra-som terapêutico em lesão muscular aguda, por meio dos resultados obtidos em ensaios mecânicos de tração. Os ensaios foram realizados em músculos tratados e não-tratados pelo ultra-som. Mostraram que os músculos tratados apresentaram diferença significativa na deformação máxima, carga e deformação no limite de proporcionalidade, e na energia absorvida na fase elástica. Sugeriram que a aplicação do ultra-som terapêutico possa melhorar a qualidade da reparação da lesão muscular aguda. 


\subsection{Objetivo}

Sabendo que a imobilização e a remobilização exercem influência na capacidade funcional do músculo, este trabalho de pesquisa foi elaborado com o objetivo de determinar e comparar as propriedades mecânicas do músculo gastrocnêmio de ratas submetidos à imobilização, remobilização livre e treinamento físico, obtidas em ensaio de tração axial. 


\section{MATERIAL E MÉTODO}

\subsection{Animais de experimentação}

Foram utilizadas ratas fêmeas (Rattus Norvegicus Albinus) da variedade Wistar, adultas jovens, com peso corporal médio de 209 gramas (variação 170 - 250g), fornecidas pelo Biotério Central da Prefeitura do Campus de Ribeirão Preto, da Universidade de São Paulo. Os animais foram mantidos em gaiolas plásticas, em número de dois, no Laboratório de Bioengenharia da Faculdade de Ribeirão Preto - USP, em temperatura ambiente, com livre acesso à água e alimentação padrão.

No início os animais foram pesados, identificados e numerados com cortes nas orelhas, sendo que o grupo submetido ao exercício foi marcado com ácido pícrico. No final do experimento foram pesados novamente.

Inicialmente, foram utilizadas 40 ratas. Um animal morreu dois dias após a chegada ao laboratório, e dois animais morreram durante o período de imobilização, restando 37 animais para a experimentação.

\subsection{Grupos experimentais}

Os 37 animais foram distribuídos aleatoriamente em 4 grupos experimentais: 1Controle, 2- Imobilização, 3- Imobilização-Exercitação, e 4 Imobilização-Liberação. O QUADRO 01 apresenta a distribuição dos animais nos grupos experimentais. 
QUADRO 01 - Distribuição dos animais nos grupos experimentais.

\begin{tabular}{|cc|}
\hline Grupos Experimentais & $\mathbf{N}^{\mathbf{0}}$ de Animais \\
\hline Controle & 9 \\
Imobilização & 10 \\
Imobilização - Exercitação & 9 \\
Imobilização - Liberação & 9 \\
\hline TOTAL & $\mathbf{3 7}$ \\
\hline
\end{tabular}

\subsection{Caracterização dos grupos}

\subsubsection{Grupo Controle}

Neste grupo, os animais, no início do experimento foram separados dos demais e, uma vez atingidos o peso entre a faixa selecionada (170-250g), foram deixados nas gaiolas por três semanas e depois, foram sacrificados.

\subsubsection{Grupo Imobilização}

Composto por 10 animais com as mesmas características físicas do grupo controle. Ao atingirem o peso entre 170-250g tiveram o membro posterior direito imobilizado durante três semanas e depois, foram sacrificados.

\subsubsection{Grupo Imobilização - Exercitação}

Composto por 9 animais com as mesmas características físicas e a mesma imobilização que o grupo anterior. Após três semanas de imobilização, esta foi retirada Depois de três dias sem a imobilização os animais foram submetidos ao exercício de natação por um período de quatro semanas. Depois, foram sacrificados. 


\subsubsection{Grupo Imobilização - Liberação}

Composto por 9 animais com as mesmas características e imobilização do grupo anterior. Porém, após a retirada da imobilização, foram deixados livres nas gaiolas durante quatro semanas e, depois, sacrificados.

\subsection{Técnica de Imobilização}

Para os grupos imobilizados o membro posterior direito foi imobilizado com aparelho gessado, que incluiu a pelve, quadril e joelho (ambos em extensão). Previamente, os animais foram anestesiados com inalação de éter sulfúrico, tendo o tronco e membro posterior direito envolvidos por uma malha tubular e ataduras de algodão com $4 \mathrm{~cm}$ de largura, para prevenir a formação de úlceras de pressão. Foi utilizada atadura gessada de secagem rápida, $4 \mathrm{~cm}$ de largura, que foi aplicada de maneira convencional. O gesso foi substituído quando danificado e as imobilizações foram mantidas por três semanas. Os animais foram colocados em gaiolas plásticas, dois a dois, com livre acesso à água e ração. $\mathrm{O}$ gesso não impedia a locomoção dentro da gaiola. A FIGURA 01 ilustra um animal imobilizado.

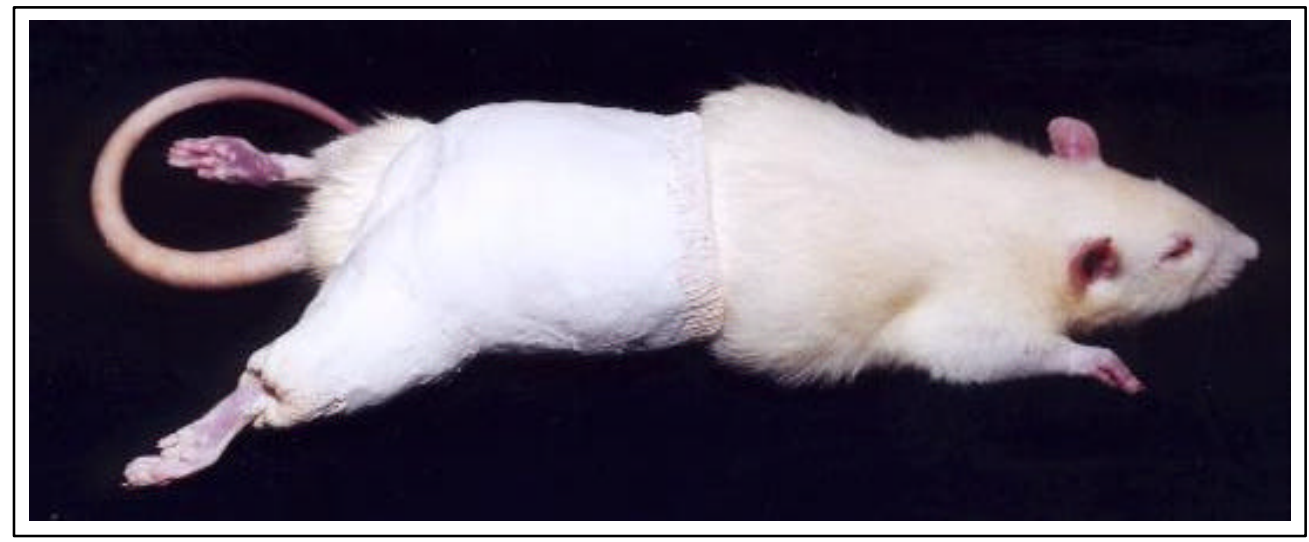

FIGURA 01 - Animal com o membro posterior direito imobilizado em aparelho gessado. 


\subsection{Técnica de Exercitação}

No grupo Imobilização-Exercitação após 3 semanas de imobilização, foi retirado o gesso e os animais submetidos a exercícios de natação em água de um reservatório de 500 litros, circular, fabricado em plástico e com profundidade de 60cm (FIGURA 02). A temperatura da água foi mantida em $32^{\circ} \mathrm{C}$, por meio de um aquecedor para aquários e em agitação leve por meio de uma bomba de água.

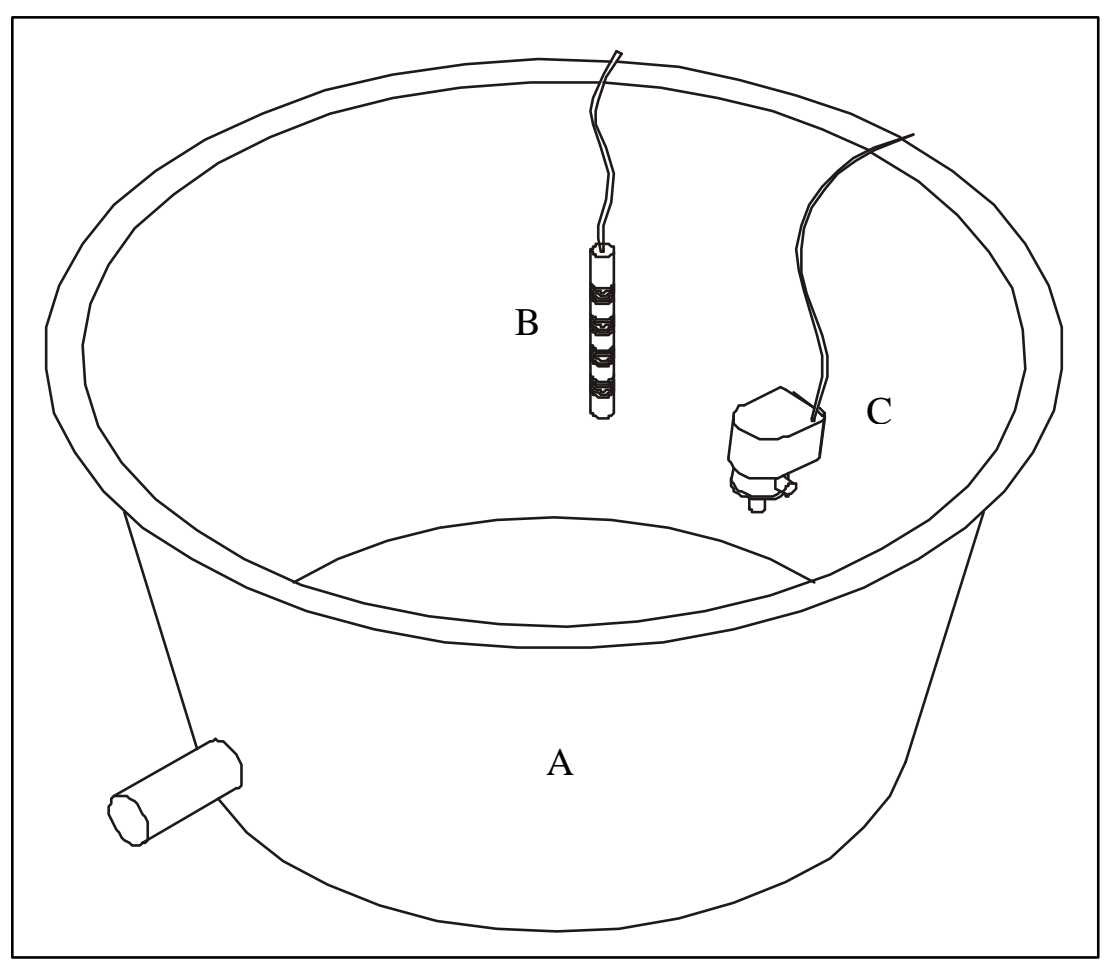

FIGURA 02 - Reservatório de água montado para realização dos exercícios. Reservatório (A), aquecedor (B) e bomba de água (C).

Para o treinamento, os animais foram submetidos a um trabalho de adaptação ao exercício. No primeiro dia de treinamento, foram colocados na água por um período de 15 minutos, sem carga, com incremento diário de 5 minutos, chegando a 35 minutos de 
treinamento no quinto dia. Após esse período os ratos passaram para o treinamento de adaptação progressiva ao esforço. Foram utilizados pesos de chumbo, previamente calibrados iniciando-se com carga de $5 \%$ do peso corporal presos a uma cinta elástica (FIGURA 03). A cinta foi colocada no tórax do rato de modo a não prejudicar a movimentação. A carga foi aumentada progressivamente até $8 \%$ do peso corporal em um período de 3 semanas e chegando a duração dos exercícios nos últimos cinco dias em 60 minutos (FIGURA 04).

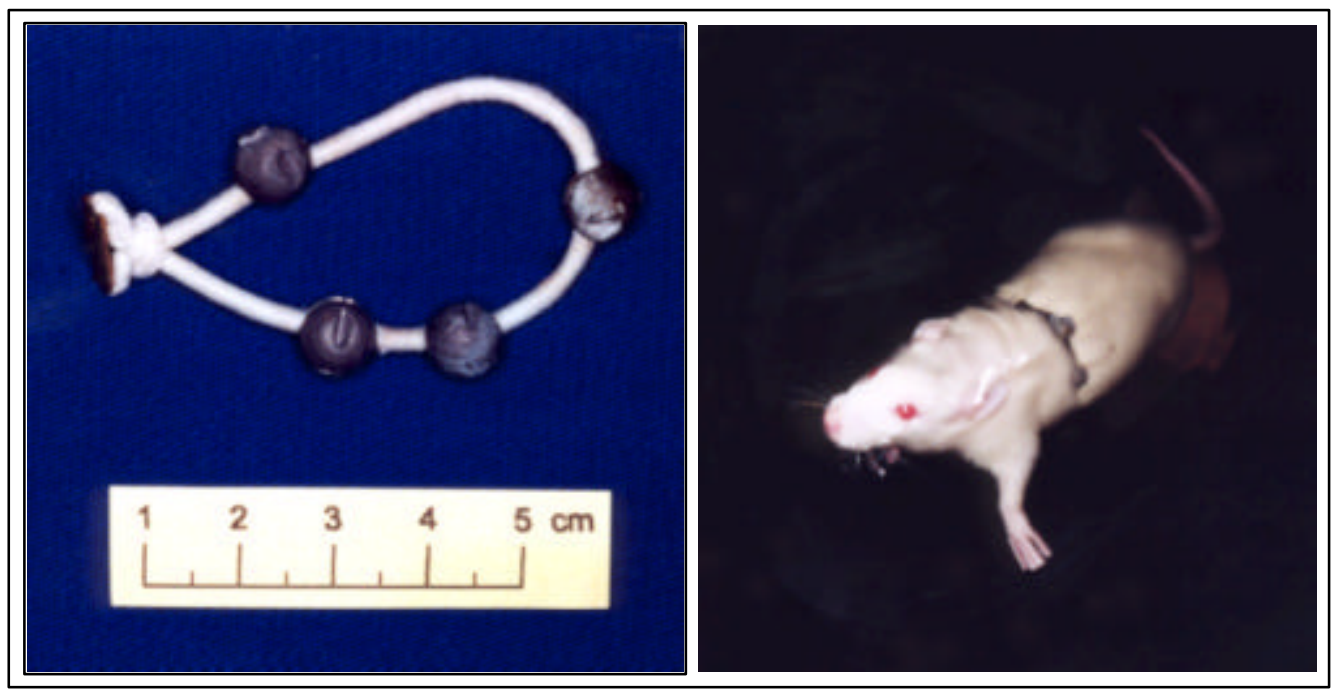

FIGURA 0 - Pesos adaptados à cinta elástica.

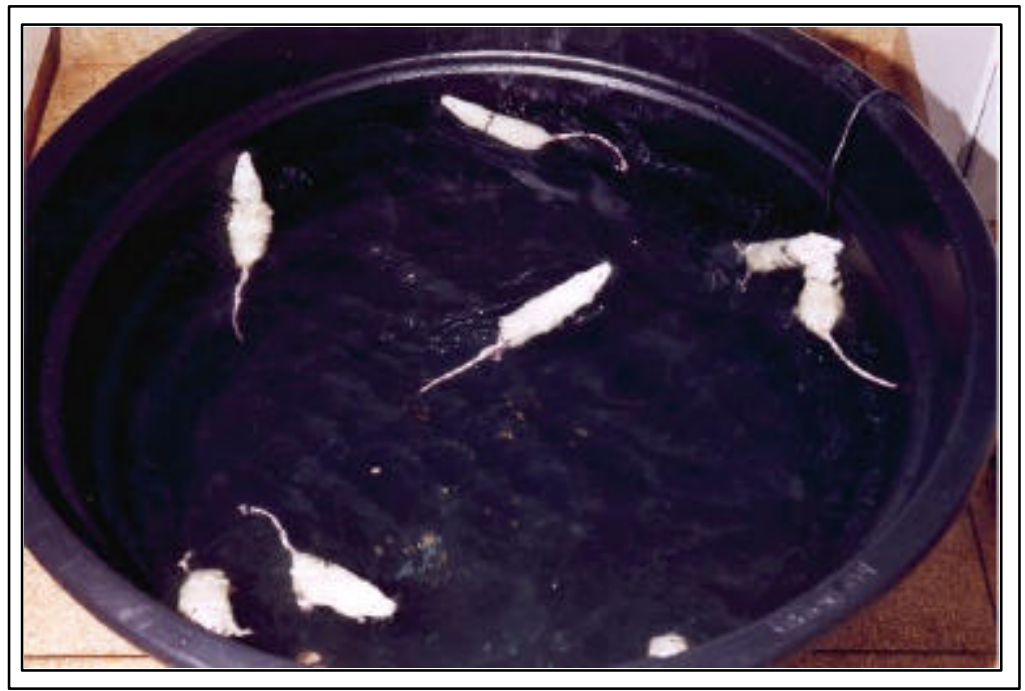

FIGURA O4 - Exercício de natação. 
O exercício foi realizado no período da manhã, 5 dias da semana com descanso aos sábados e domingos. As cargas foram colocadas como um estímulo ao exercício, dentro dos limites de condições aeróbicas, inclusive para o tempo estabelecido. Após o término da sessão de natação os animais foram secos com jato de ar quente produzido por um secador de cabelos e, depois, recolocados nas gaiolas. Após o período de quatro semanas em que foram submetidos aos exercícios, foram sacrificados.

Os animais do grupo Imobilização-Liberação, após a retirada da imobilização, permaneceram pelo mesmo período de quatro semanas, em suas gaiolas, com livre acesso à água e ração. Após esse período os animais foram sacrificados .

\subsection{Coleta de material}

Finda a fase experimental, todos os animais foram sacrificados por inalação excessiva de éter sulfúrico.

De cada animal foi retirado o membro posterior direito por desarticulação do quadril. A pele foi removida e o músculo gastrocnêmio foi dissecado, mantendo-se sua origem no terço distal do fêmur e a inserção no calcâneo, e, em seguida, colocado em solução de lactato de Ringer, em temperatura ambiente, até a realização do ensaio mecânico. A peça obtida para o ensaio pode ser vista na FIGURA 05.

No momento da coleta do material, atentou-se para o trofismo, coloração do músculo, definição das fibras musculares, aderências da pele ou espessamentos do tecido conjuntivo. A verificação da mobilidade articular para a articulação do joelho foi realizada por meio de mobilização passiva para flexão máxima e extensão máxima, fazendo-se uma avaliação grosseira do ângulo. 


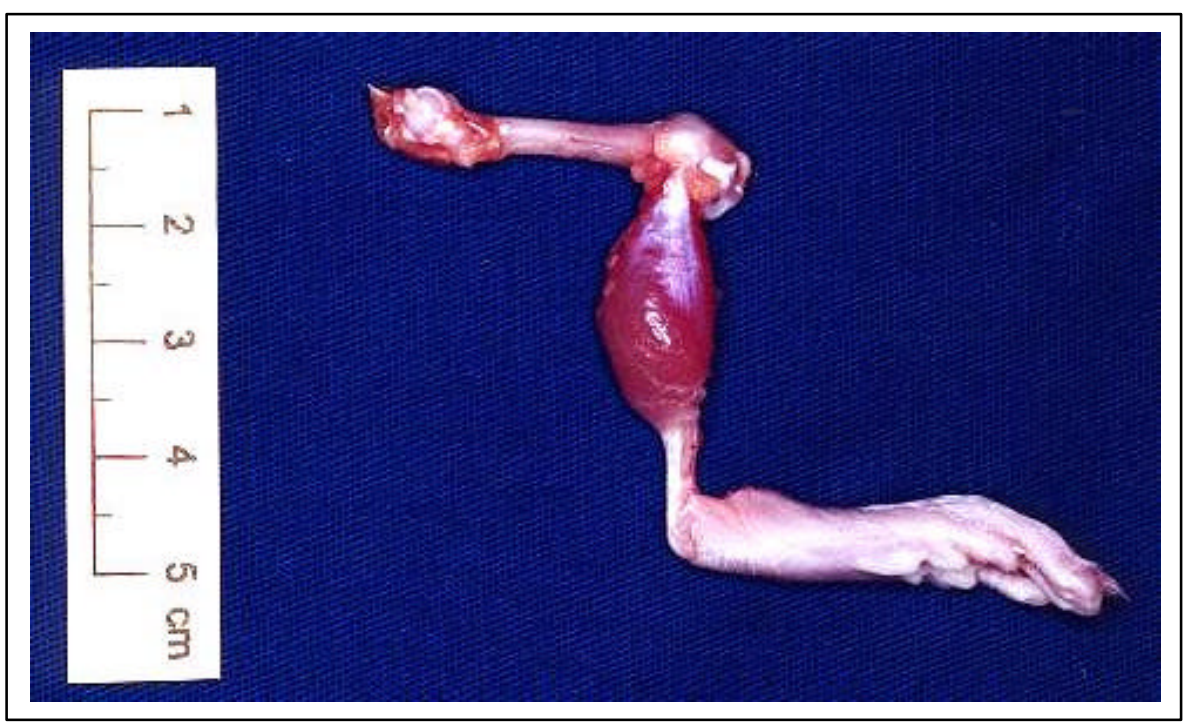

FIGURA Cक - Peça obtida para o ensaio mecânico mostrando o gastrocnêmio, com preservação da origem femoral e inserção no calcâneo.

\subsection{Ensaio mecânico de tração}

Para o ensaio de tração do músculo gastrocnêmio foi utilizada a máquina universal de ensaio do Laboratório de Bioengenharia da Faculdade de Medicina de Ribeirão Preto USP, equipada com célula de carga com capacidade de $200 \mathrm{kgf}$ (Kratos $\left.{ }^{\circledR}\right)$, ligada a uma ponte de extensometria (Sodmex®) para medida da carga aplicada (FIGURA 06). As deformações foram fornecidas por um relógio comparador (Mitutoyo®), com a precisão de 0,01mm, correspondentes à cada deformação medida.

Dois acessórios foram confeccionados na Oficina Mecânica de Precisão da Prefeitura do Campus de Ribeirão Preto, da Universidade de São Paulo, para a fixação da peça a ser estudada, sendo um para fixação do fêmur e outro para fixação do calcâneo, mantendo o joelho e tornozelo com $90^{\circ}$ de angulação (FIGURA 06).

Imediatamente antes do ensaio mecânico, o comprimento do músculo gastrocnêmio foi medido com um paquímetro digital (Mitutoyoß), inicialmente após ser fixado na 
máquina universal de ensaio e depois de ter recebido a pré-carga de 200 gramas, com tempo de acomodação de 60 segundos. A velocidade estabelecida para o ensaio foi de $5 \mathrm{~mm} /$ minuto e as medidas realizadas a cada $0,5 \mathrm{~mm}$.

O diâmetro do músculo foi medido na região do ventre muscular com um cordonê. $\mathrm{O}$ cordonê foi alçado em torno da parte mais volumosa do ventre muscular e tracionado de modo a que ele ficasse apenas em contato com o músculo, sem provocar depressão. Depois disto o cordonê foi medido com um paquímetro digital (Mitutoyo ${ }^{\circledR}$ ). As peças estudadas foram pesadas antes do ensaio, em balança digital com precisão de 0,01 grama, modelo Precision- $\operatorname{Pr} 500^{\circledR}$.

Após a fixação do músculo nos acessórios da máquina universal de ensaios, ele foi submetido à tração axial. Os ensaios foram realizados até a décima leitura após o limite máximo, registrando-se as cargas correspondentes a cada deformação medida. Após a realização de cada ensaio, foi realizada inspeção do local de ruptura da peça.

Todos os músculos foram ensaiados em um período máximo de 1 hora e 30 minutos após a coleta e, durante este tempo, foram mantidos imersos em solução de lactato de Ringer, à temperatura ambiente. Durante o ensaio mecânico foram borrifados com a mesma solução para manter a hidratação dos tecidos. 


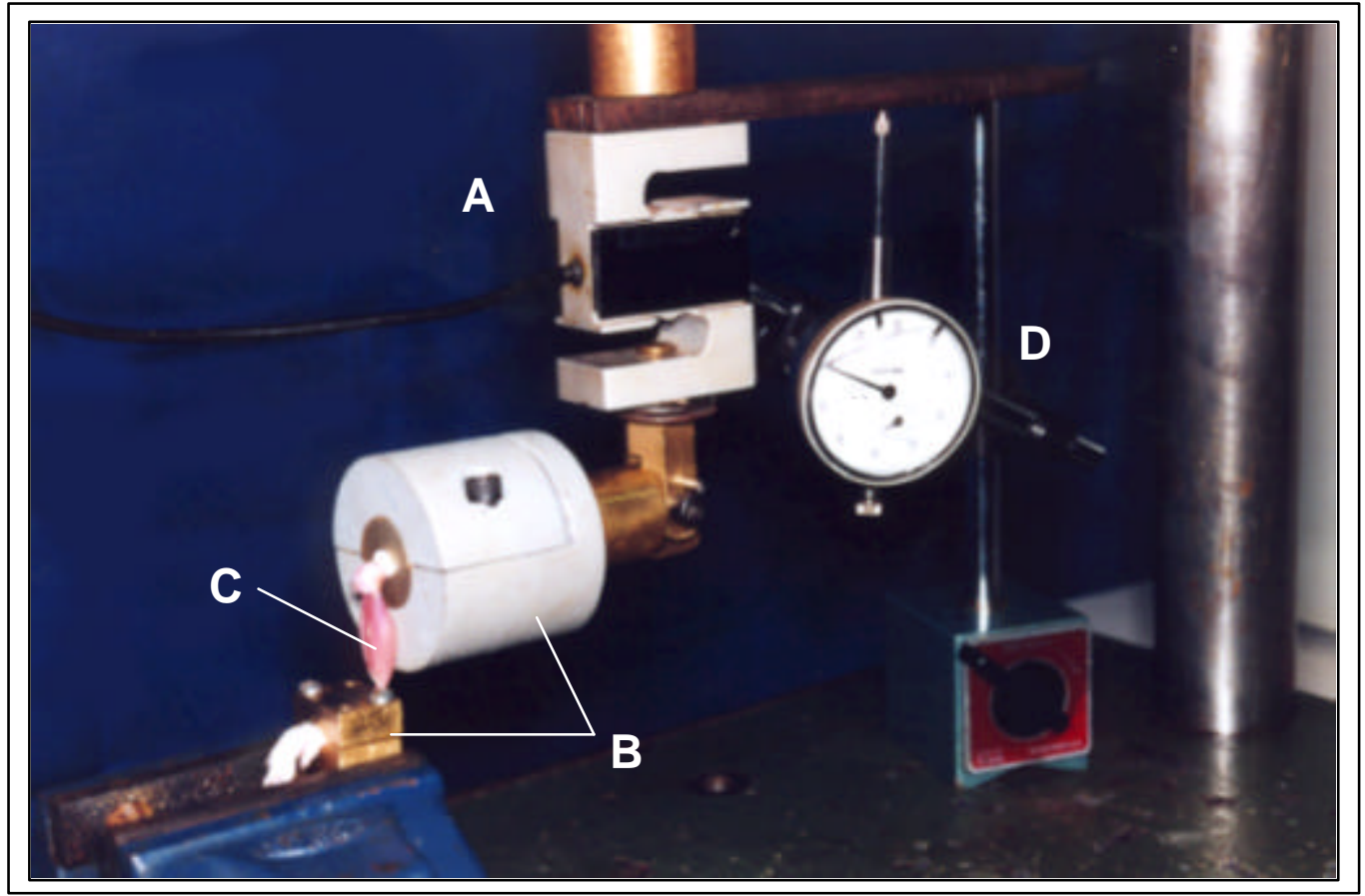

FIGURA 06 - Montagem para a realização do ensaio de tração axial na máquina universal de ensaios. Célula de carga (A), acessórios para fixação do músculo (B), músculo (C) e relógio comparador (D)

\subsubsection{Propriedades mecânicas}

Com os gráficos carga $x$ deformação, obtidos de cada ensaio, foram calculadas as seguintes propriedades mecânicas: limite de proporcionalidade, limite máximo, rigidez e energia absorvida pelo músculo na fase elástica (resiliência).

A FIGURA 07 ilustra como foram determinadas as propriedades mecânicas: LP representa o limite de proporcionalidade, LM representa o limite máximo, e, a área representada pelo triângulo O-A-LP representa a resiliência. 


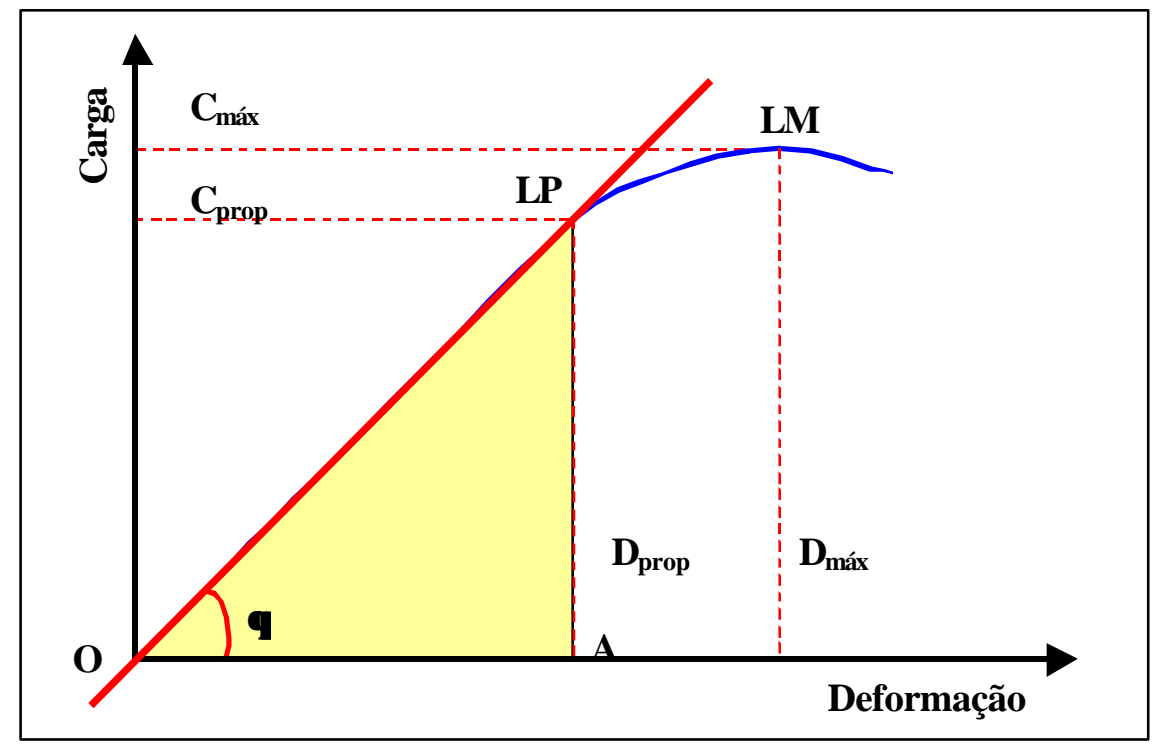

FIGURA $\boldsymbol{\phi}$ - Gráfico carga $x$ deformação, a partir do qual são obtidas as principais propriedades mecânicas do ensaio de tração.

\subsubsection{Limite de proporcionalidade (LP)}

O limite de proporcionalidade é identificado como sendo o último ponto onde se encontra o segmento linear do gráfico carga versus deformação.

Para determinar o LP, foi traçada uma curva de regressão, seguindo a inclinação e identificando o último ponto da reta. As coordenadas deste ponto representam o limite de proporcionalidade para carga e deformação.

\subsubsection{Limite máximo $(L M)$}

O limite máximo é o maior valor da carga e deformação observados em cada ensaio, até o rompimento do músculo. 


\subsubsection{Rigidez $(R)$}

A rigidez é obtida na fase elástica do material, determinada pela inclinação da curva carga versus deformação, calculada pela tangente do ângulo $\boldsymbol{\theta}$ formado pela reta que representa a inclinação da curva e uma linha traçada horizontalmente a partir do ponto do início do ensaio e é dada pela equação:

$$
R=T g \theta=\frac{C_{P r o p}}{D_{\text {Prop }}}
$$

\subsubsection{Resiliência (E’) - (Energia absorvida na fase elástica)}

Resiliência é a capacidade do material absorver energia na fase elástica do material. A resiliência é obtida calculando-se a área abaixo da curva carga versus deformação na região elástica, delimitada pelo triângulo O-A-LP na FIGURA 07. É dada pela equação:

$$
E=\text { área do } \Delta=\frac{C_{\text {Prop }} \cdot D_{\text {Prop }}}{2}
$$

\subsection{Análise estatística}

Os dados obtidos para cada animal foram somados e calculadas as médias aritméticas.

Para análise estatística foi utilizado o Teste de Tukey. O nível de significância foi estabelecido em 5 por cento.

Os testes foram processados utilizando-se o programa Sigma Stat v.2.03 ${ }^{\circledR}$. 


\section{RESULTADOS}

Os valores médios do peso corporal dos animais nos diferentes grupos e após os períodos de procedimentos podem ser observados na TABELA 01.

TABELA 1 - Peso corporal inicial e final.

\begin{tabular}{|c|c|c|}
\hline Grupos & Períodos & Peso corporal $(\mathrm{g})$ \\
\hline \multirow{2}{*}{ Controle } & Inicial & $196,66 \pm 13,69$ \\
\hline & Após 3 semanas & $231,66 \pm 10,60$ \\
\hline \multirow{2}{*}{ Imobilização } & Inicial & $231,66 \pm 10,60$ \\
\hline & Após 3 semanas de imobilização & $187,50 \pm 17,78$ \\
\hline \multirow{3}{*}{$\begin{array}{l}\text { Imobilização } \\
\text { Exercitação }\end{array}$} & Inicial & $193,88 \pm 17,99$ \\
\hline & Após 3 semanas de imobilização & $177,77 \pm 20,01$ \\
\hline & Após 4 semanas de exercitação & $265,00 \pm 25,00$ \\
\hline \multirow{3}{*}{$\begin{array}{c}\text { Imobilização } \\
\text { Liberação }\end{array}$} & Inicial & $209,44 \pm 21,27$ \\
\hline & Após 3 semanas de imobilização & $206,11 \pm 31,10$ \\
\hline & Após 4 semanas de liberação & $277,77 \pm 37,50$ \\
\hline
\end{tabular}

Os valores médios do peso das peças e do diâmetro dos músculos obtidos para os ensaios, podem ser vistos na TABELA 02.

TABELA 02 - Valores médios do peso da peça e do diâmetro do músculo gastrocnêmio

\begin{tabular}{ccccc}
\hline & Grupos & & \\
& Controle & Imobilização & $\begin{array}{c}\text { Imobilização } \\
\text { Exercitação }\end{array}$ & $\begin{array}{c}\text { Imobilização } \\
\text { Liberação }\end{array}$ \\
\hline $\begin{array}{c}\text { Peso da peça } \\
\text { (gramas) }\end{array}$ & $4,67 \pm 0,40$ & $3,69 \pm 0,41$ & $4,92 \pm 0,46$ & $5,48 \pm 0,93$ \\
$\begin{array}{c}\text { Diâmetro do } \\
\text { ventre muscular } \\
(\text { mm) }\end{array}$ & $32,82 \pm 1,64$ & $25,38 \pm 1,67$ & $32,68 \pm 1,47$ & $33,85 \pm 1,48$ \\
\hline
\end{tabular}


Houve diferença estatisticamente significante $(\mathrm{p}<0,05)$ nas comparações dos valores obtidos para o peso das peças no grupo Imobilização em relação aos grupos Controle, Imobilização-Exercitação e Imobilização-Liberação. Não foi observada diferença significante nas comparações Controle $x$ Imobilização-Exercitação e Controle $x$ Imobilização-Liberação.

Os valores médios obtidos para o diâmetro do ventre muscular foram analisados, não sendo encontradas diferenças significantes nas comparações Controle $x$ ImobilizaçãoExercitação, Contole $x$ Imobilização-Liberação $\mathrm{e}$ Imobilização-Exercitação $x$ ImobilizaçãoLiberação.. Na comparação dos valores obtidos para o grupo Imobilização com os demais grupos, houve diferença estatisticamente significante, com $\mathrm{p}<0,05$.

Os músculos dos animais submetidos à imobilização e sacrificados logo após a retirada, macroscopicamente, apresentaram atrofia e coloração esbranquiçada, e, ao serem dissecados, apresentaram áreas de "espessamento fibroso".

Os músculos dos animais submetidos à imobilização e deixados livres após a retirada da imobilização apresentaram-se com coloração rosada, volume semelhante ao grupo controle, algumas vezes aderido à pele e com pouca definição das fibras musculares.

Os membros imobilizados apresentaram uma pequena diminuição na amplitude articular do joelho para flexão/ extensão completa. Os animais submetidos à reabilitação apresentaram recuperação da amplitude, e o grupo não exercitado apresentou um animal com limitação permanente para extensão completa do joelho.

Houve formação de úlceras cutâneas de pressão na pata de 2 animais do grupo Imobilização, 1 animal do grupo Imobilização-Liberação e 2 animais do grupo ImobilizaçãoExercitação, que se cicatrizaram espontaneamente, após a retirada da imobilização (TABELA 03). 
TABELA 03 - Caracterização macroscópica dos músculos gatrocnêmios nos grupos experimentais.

\begin{tabular}{ccccc}
\hline Características & Controle & Imobilização & $\begin{array}{c}\text { Imobilização } \\
\text { Exercitação }\end{array}$ & $\begin{array}{c}\text { Imobilização } \\
\text { Liberação }\end{array}$ \\
\hline Trofismo & Normal & Atrofia & Normal & Normal \\
$\begin{array}{c}\text { Coloração da } \\
\text { musculatura }\end{array}$ & Rosada & Esbranquiçada & Rosada & Rosada \\
$\begin{array}{c}\text { Definição das } \\
\text { fibras } \\
\text { musculares }\end{array}$ & Definidas & $\begin{array}{c}\text { Muito pouco } \\
\text { definidas }\end{array}$ & $\begin{array}{c}\text { Muito bem } \\
\text { definidas }\end{array}$ & $\begin{array}{c}\text { Pouco } \\
\text { definidas }\end{array}$ \\
$\begin{array}{c}\text { Amplitude } \\
\text { articular }\end{array}$ & Normal & $\begin{array}{c}\text { Diminuída para } \\
\text { extensão }\end{array}$ & Normal & $\begin{array}{c}\text { pira extensão } \\
\text { em 1 animal }\end{array}$ \\
\hline
\end{tabular}

Foram ensaiados 37 músculos sendo que, destes, 32 foram aproveitados para análise dos gráficos carga $x$ deformação. Cinco ensaios foram excluídos por apresentarem grande variação da dispersão nas curvas.

Com a tração, no grupo Controle, 6 músculos romperam no ventre muscular e 3 romperam na inserção no osso calcâneo, sendo que para 1 deles houve avulsão óssea.

Para o grupo Imobilização, 2 músculos romperam na origem no osso fêmur e os demais músculos romperam no ventre muscular.

Nos músculos do grupo Imobilização-Exercitação, a ruptura ocorreu no ventre muscular em todos os casos, e para o grupo Imobilização-Liberação, 1 músculo rompeu na inserção com avulsão de fragmento do calcâneo e, outro, na origem. Os demais músculos do grupo romperam no ventre muscular (TABELA 04). 
TABELA 04 - Local de ruptura dos músculos gastrocnêmio durante o ensaio mecânico, nos diferentes grupos.

\begin{tabular}{cccc}
\hline & \multicolumn{3}{c}{ Local de Ruptura } \\
\hline & Ventre muscular & Origem & Inserção \\
\hline Controle & 6 & 0 & 3 \\
Imobilização & 8 & 2 & 0 \\
Imobilização Exercitação & 9 & 0 & 0 \\
Imobilização Liberação & 7 & 1 & 1 \\
\hline TOTAL & $\mathbf{3 0}$ & $\mathbf{3}$ & $\mathbf{4}$ \\
\hline
\end{tabular}

A ruptura ocorreu no ventre muscular em $81 \%$ dos casos. Observamos rompimento na origem muscular em $8 \%$ dos casos e, $11 \%$ romperam-se na inserção no osso calcâneo.

Foi observado que dois dos três animais que apresentaram rompimento muscular na origem apresentavam limitação articular para completa extensão do joelho. 


\subsection{Curvas carga $x$ deformação}

As curvas carga $x$ deformação obtidas nos grupos Controle, Imobilização, Imobilização-Exercitação e Imobilização-Liberação, são apresentados nas FIGURAS 08 a onze. As TABELAS 05 a 08 mostram os valores das propriedades mecânicas obtidas com as respectivas médias e desvio padrão.

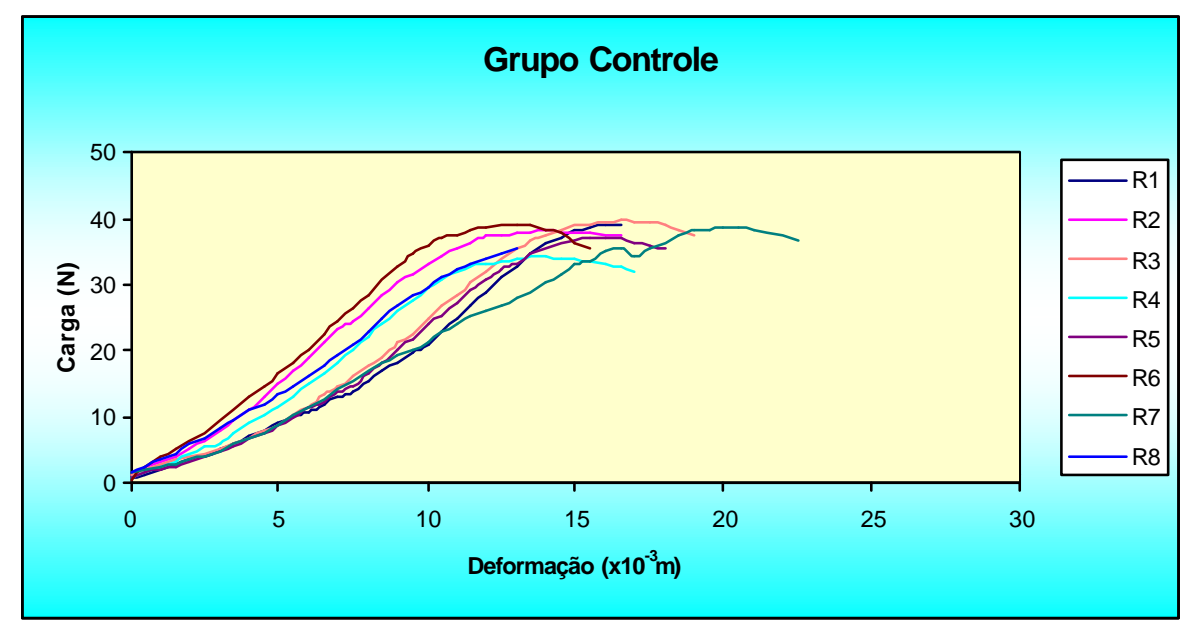

FIGURA 08 - Curvas carga $x$ deformação dos 8 músculos analisados no grupo controle.

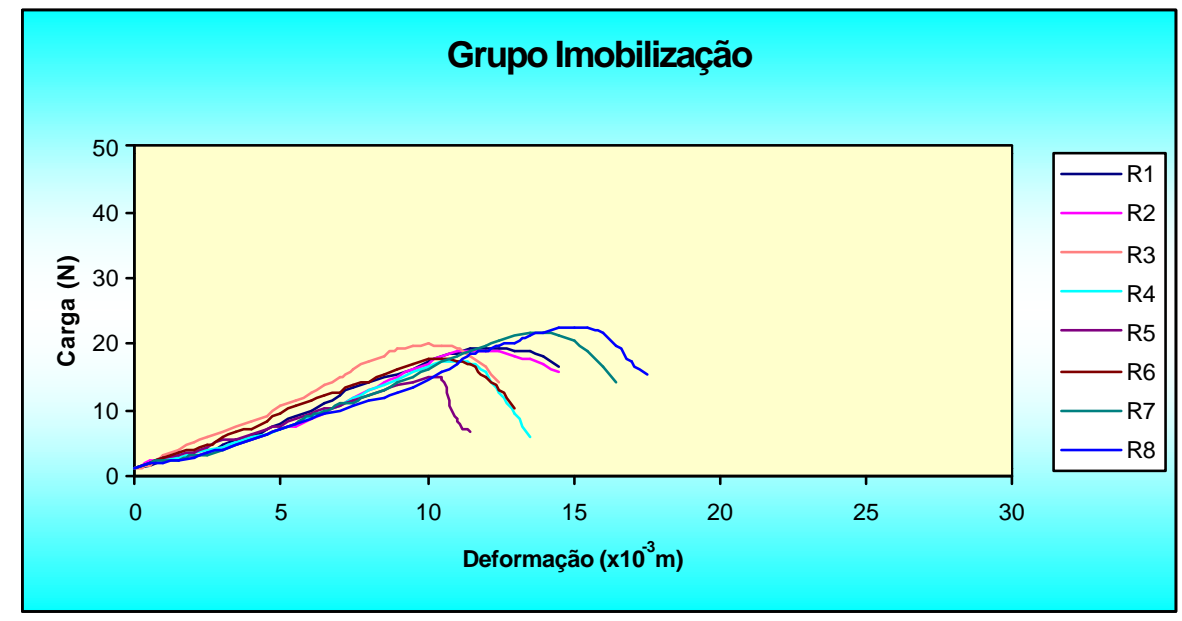

FIGURA 09 - Curvas carga $x$ deformação dos 8 músculos analisados no grupo imobilizados e sacrificados imediatamente após a retirada da imobilização. 


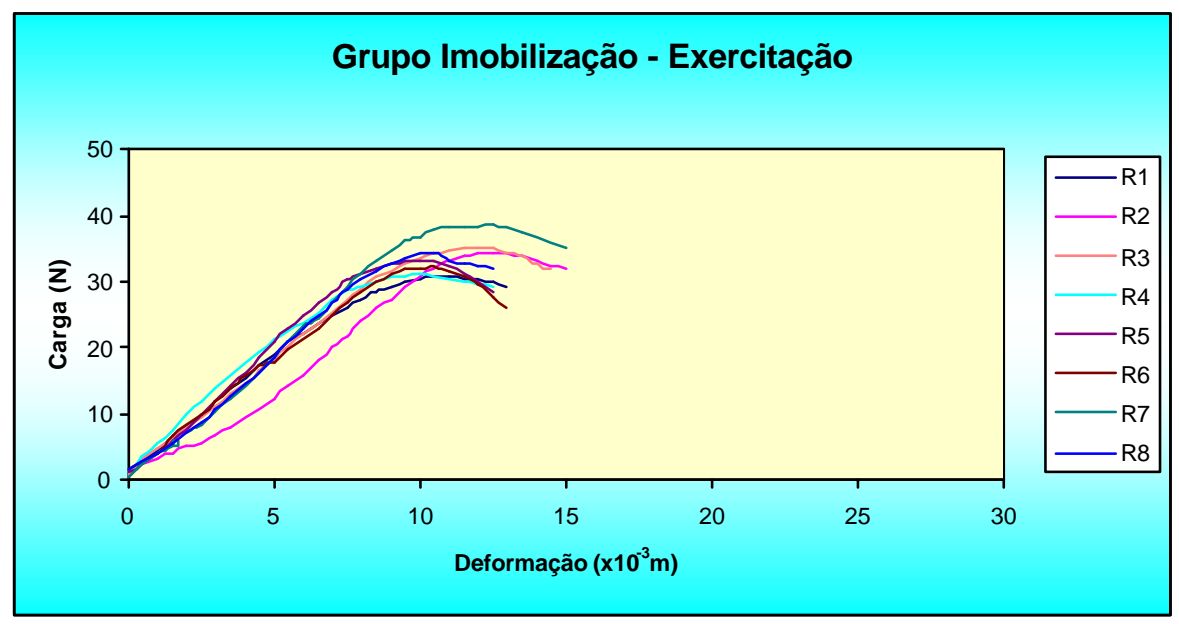

FIGURA 10 - Curvas carga $x$ deformação dos 8 músculos analisados no grupo imobilizado e exercitado após a retirada da imobilização.

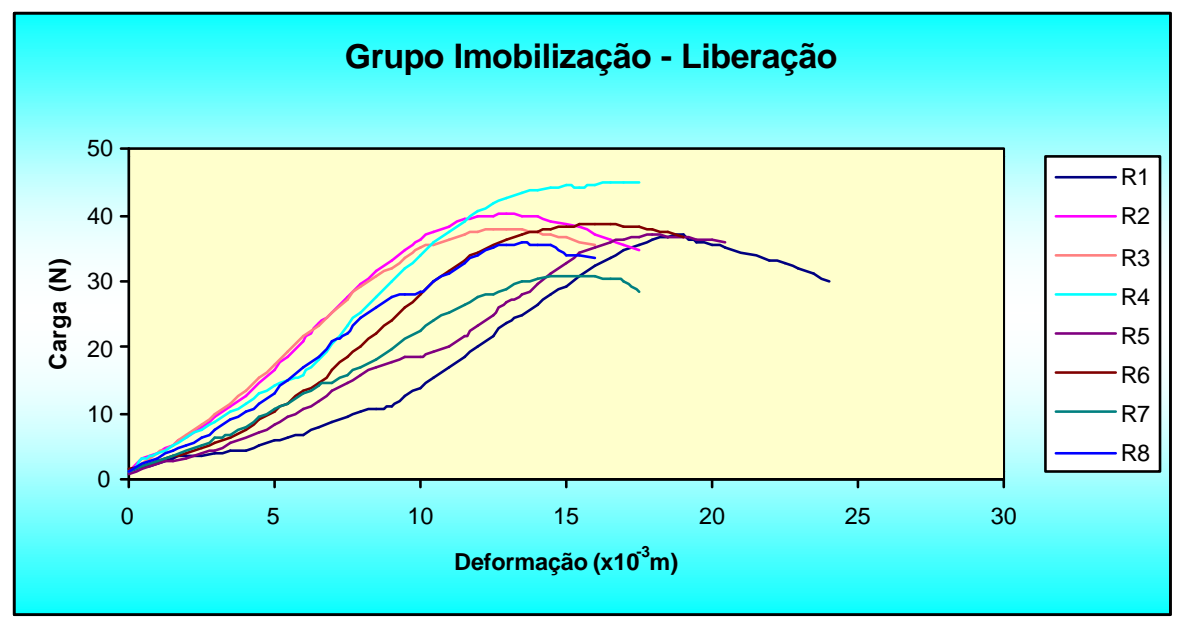

FIGURA 11 - Curvas carga $x$ deformação dos músculos analisados no grupo imobilizado e não exercitado após a retirada da imobilização. 
TABELA 05 - Valores das propriedades mecânicas dos músculos dos animais do grupo Controle.

\begin{tabular}{|c|c|c|c|c|c|c|}
\hline \multirow[t]{2}{*}{ Rato } & \multicolumn{2}{|c|}{ Limite máximo } & \multicolumn{2}{|c|}{$\begin{array}{c}\text { Limite de } \\
\text { proporcionalidade }\end{array}$} & \multirow{2}{*}{$\frac{R}{3 \mathrm{~m}) \times 10^{3} \mathrm{~N} / \mathrm{m}}$} & \multirow{2}{*}{$\frac{E^{\prime}}{x 10^{-3} J}$} \\
\hline & Cmáx(N & $\overline{x\left(x 10^{-3} \mathrm{~m}\right)}$ & $\overline{C p r o p(N)}$ & $\operatorname{dprop}\left(x 10^{-3}\right.$ & & \\
\hline 1 & 39,24 & 16,0 & 36,20 & 11,76 & 3,08 & 212,85 \\
\hline 2 & 38,06 & 14,0 & 34,43 & 10,24 & 3,36 & 176,28 \\
\hline 3 & 39,73 & 16,5 & 36,69 & 11,92 & 3,08 & 218,67 \\
\hline 4 & 34,14 & 13,5 & 30,80 & 9,71 & 3,17 & 149,53 \\
\hline 5 & 37,08 & 15,5 & 33,35 & 10,76 & 3,10 & 179,42 \\
\hline 6 & 38,85 & 12,5 & 34,63 & 9,24 & 3,75 & 159,99 \\
\hline 7 & 35,71 & 16,5 & 33,65 & 14,58 & 2,31 & 245,31 \\
\hline 8 & 35,31 & 13,0 & 32,27 & 11,32 & 2,85 & 182,65 \\
\hline média & 37,27 & 14,69 & 34,00 & 12,19 & 3,09 & 190,59 \\
\hline $\mathrm{dp}$ & 2,04 & 1,62 & 1,94 & 2,10 & 0,41 & 32,28 \\
\hline
\end{tabular}

$\mathrm{dp}=$ desvio padrão

$\mathrm{R}=$ Rigide $\mathrm{z}$

$E^{\prime}=$ Resiliência

TABELA 06 - Valores das propriedades mecânicas dos músculos dos animais do grupo Imobilização.

\begin{tabular}{ccccccc}
\hline Rato & Limite máximo & $\begin{array}{c}\text { Limite de } \\
\text { proporcionalidade }\end{array}$ & $\mathbf{R}$ & $\mathbf{E}^{\prime}$ \\
\hline & Cmáx(N) & $\mathbf{d m a ́ x}\left(\mathbf{x 1 0}^{-3} \mathbf{m}\right)$ & $\mathbf{C p r o p}(\mathbf{N})$ & $\mathbf{d p r o p}\left(\mathbf{x 1 0}^{-3} \mathbf{m}\right) \mathbf{x 1 0} \mathbf{3} \mathbf{N} \mathbf{m}$ & $\mathbf{x 1 0}^{-3} \mathbf{J}$ \\
\hline 1 & 19,52 & 12,00 & 18,15 & 10,50 & 1,73 & 95,28 \\
2 & 19,13 & 12,00 & 17,95 & 10,50 & 1,71 & 94,23 \\
3 & 20,01 & 10,00 & 18,24 & 9,00 & 2,02 & 82,08 \\
4 & 17,26 & 11,00 & 16,58 & 10,00 & 1,66 & 82,90 \\
5 & 14,81 & 10,00 & 13,34 & 9,50 & 1,40 & 68,02 \\
6 & 17,76 & 10,50 & 16,67 & 10,00 & 1,67 & 83,35 \\
7 & 21,78 & 14,00 & 20,50 & 12,24 & 1,67 & 125,46 \\
8 & 22,46 & 15,00 & 21,28 & 13,24 & 1,61 & 140,87 \\
\hline média & 19,09 & 11,81 & 18,21 & 10,69 & 1,68 & 96,52 \\
\hline dp & 2,48 & 1,85 & 2,20 & 1,53 & 0,17 & 22,89 \\
\hline
\end{tabular}

$\mathrm{dp}=$ desvio padrão

$\mathrm{R}=$ Rigidez

$\mathrm{E}^{\prime}=$ Resiliência 
TABELA 07 - Valores das propriedades mecânicas dos músculos dos animais do grupo Imobilização-Exercitação.

\begin{tabular}{|c|c|c|c|c|c|c|}
\hline \multirow[t]{2}{*}{ Rato } & \multicolumn{2}{|c|}{ Limite máximo } & \multicolumn{2}{|c|}{$\begin{array}{c}\text { Limite de } \\
\text { proporcionalidade }\end{array}$} & \multirow{2}{*}{$\frac{R}{x 10^{3} \mathrm{~N} / \mathrm{m}}$} & \multirow{2}{*}{$\frac{E^{\prime}}{x 10^{-3} J}$} \\
\hline & Cmáx(N) & dmáx $\left(x_{10}^{-3} \mathrm{~m}\right)$ & $\overline{C p r o p(N)}$ & $\operatorname{dprop}\left(x_{10}^{-3} \mathrm{~m}\right)$ & & \\
\hline 1 & 30,70 & 10,50 & 25,21 & 7,50 & 3,36 & 94,54 \\
\hline 2 & 34,43 & 12,00 & 31,10 & 9,50 & 3,27 & 147,72 \\
\hline 3 & 35,02 & 12,00 & 30,71 & 9,00 & 3,41 & 138,19 \\
\hline 4 & 31,20 & 10,00 & 28,06 & 8,00 & 3,51 & 112,24 \\
\hline 5 & 33,25 & 10,00 & 29,83 & 8,00 & 3,73 & 119,32 \\
\hline 6 & 32,08 & 10,00 & 29,53 & 9,00 & 3,28 & 132,88 \\
\hline 7 & 38,35 & 11,00 & 35,52 & 9,50 & 3,74 & 168,72 \\
\hline 8 & 34,33 & 10,50 & 31,19 & 9,00 & 3,46 & 140,35 \\
\hline média & 33,67 & 10,75 & 31,32 & 8,69 & 3,47 & 131,75 \\
\hline $\mathrm{dp}$ & 2,46 & 0,85 & 2,87 & 0,75 & 0,18 & 22,86 \\
\hline
\end{tabular}

$\mathrm{dp}=$ desvio padrão

$\mathrm{R}=$ Rigide $\mathrm{z}$

$E^{\prime}=$ Resiliência

TABELA 08 - Valores das propriedades mecânicas dos músculos dos animais do grupo Imobilização-Liberação.

\begin{tabular}{|c|c|c|c|c|c|c|}
\hline \multirow[t]{2}{*}{ Rato } & \multicolumn{2}{|c|}{ Limite máximo } & \multicolumn{2}{|c|}{$\begin{array}{c}\text { Limite de } \\
\text { proporcionalidade }\end{array}$} & \multirow{2}{*}{$\frac{R}{x 10^{3} \mathrm{~N} / \mathrm{m}}$} & \multirow{2}{*}{$\frac{\mathbf{E}^{\prime}}{\mathbf{x 1 0 ^ { - 3 } \mathbf { J }}}$} \\
\hline & Cmáx(N) & $a ́ x\left(x 10^{-3}\right.$ & Cprop(N) & $\operatorname{dprop}\left(\mathrm{x}^{\left.-30^{-3} \mathrm{~m}\right)}\right.$ & & \\
\hline 1 & 36,98 & 19,00 & 34,53 & 12,79 & 2,70 & 220,82 \\
\hline 2 & 40,22 & 13,00 & 37,47 & 10,37 & 3,61 & 194,28 \\
\hline 3 & 37,67 & 12,50 & 33,84 & 10,00 & 3,38 & 169,20 \\
\hline 4 & 43,93 & 15,00 & 41,79 & 12,24 & 3,41 & 255,75 \\
\hline 5 & 36,98 & 18,00 & 34,23 & 13,66 & 2,51 & 233,80 \\
\hline 6 & 38,75 & 16,50 & 35,61 & 10,92 & 3,26 & 194,43 \\
\hline 7 & 30,80 & 15,00 & 28,15 & 12,37 & 2,27 & 174,10 \\
\hline 8 & 35,80 & 13,50 & 32,96 & 11,50 & 2,86 & 189,52 \\
\hline média & 37,64 & 15,31 & 34,96 & 12,75 & 3,00 & 203,99 \\
\hline $\mathrm{dp}$ & 3,75 & 2,36 & 3,86 & 2,39 & $\overline{0,48}$ & 30,12 \\
\hline
\end{tabular}

$\mathrm{dp}=$ desvio padrão

$\mathrm{R}=$ Rigidez

$E^{\prime}=$ Resiliência 


\subsection{Carga máxima}

O valor médio de carga máxima para os músculos Controle foi $(37,27 \pm 2,04) \mathrm{N}$, para os músculos Imobilização foi $(19,09 \pm 2,48) \mathrm{N}$, para os músculos Imobilização-Exercitação $(33,67 \pm 2,46) \mathrm{N}$ e para os músculos Imobilização-Liberação $(37,64 \pm 3,75) \mathrm{N}$. A comparação entre as cargas máximas mostrou que houve diferença significativa entre eles com $p<0,05$, exceto Controle $x$ Imobilização-Exercitação e Imobilização-Liberação $x$ Controle. (FIGURA 12.

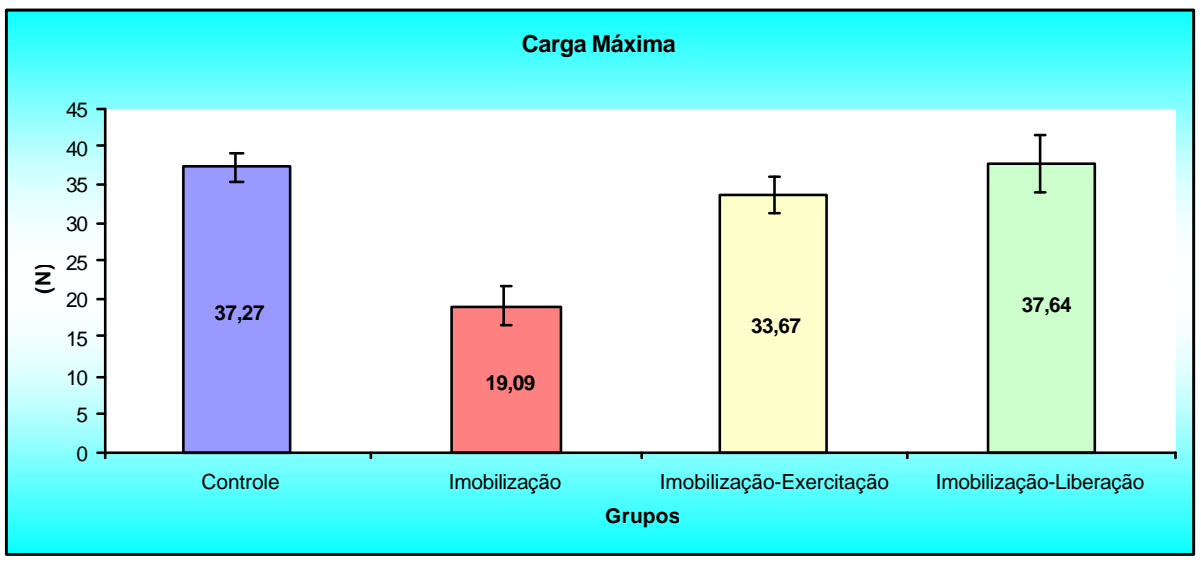

FIGURA 12 - Comparação entre os valores médios das cargas máximas. 


\subsection{Deformação máxima}

O valor médio para a deformação máxima foi $(14,69 \pm 1,62) 10^{-3} \mathrm{~m}$ para os músculos Controle, $(11,81 \pm 1,85) 10^{-3} \mathrm{~m}$ para o grupo Imobilização, $(10,75 \pm 0,85) 10^{-3} \mathrm{~m}$ para o grupo Imobilização-Exercitação, e $(15,31 \pm 2,36) 10^{-3} \mathrm{~m}$ para o grupo Imobilização-Liberação.

A comparação entre os grupos mostrou que houve diferença significativa entre eles com $\mathrm{p}<0,05$, exceto Controle $x$ Imobilização-Liberação e Imobilização $x$ ImobilizaçãoExercitação (FIGURA 13).

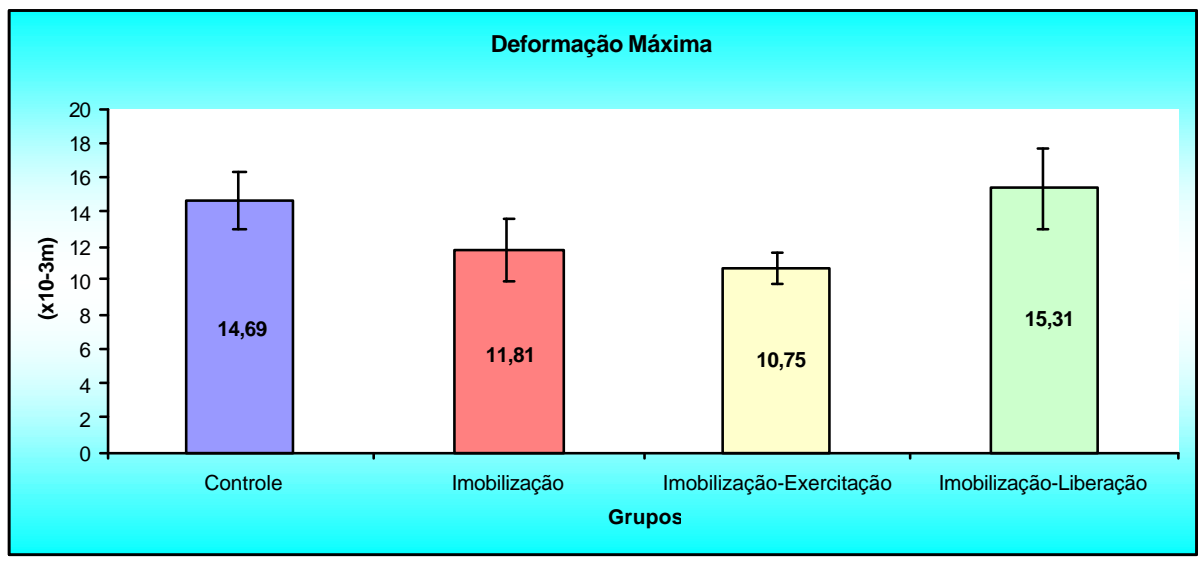

FIGURA 13 - Comparação entre os valores médios das deformações máximas nos diferentes grupos. 


\subsection{Carga no Limite de Proporcionalidade}

O valor médio para a carga proporcional foi $(34,00 \pm 1,94) \mathrm{N}$ para os músculos Controle, $(18,21 \pm 2,20) \mathrm{N}$ para o grupo Imobilização, $(31,32 \pm 2,87) \mathrm{N}$ para o grupo Imobilização-Exercitação, e $(34,96 \pm 3,86) \mathrm{N}$ para o grupo Imobilização-Liberação. A comparação entre os grupos Controle $x$ Imobilização, Imobilização-Exercitação $x$ Imobilização e Imobilização-Liberação $x$ Imobilização mostrou que houve diferença significativa com $\mathrm{p}<0,05$. A comparação entre Controle $x$ Imobilização-Exercitação, Controle $x$ Imobilização-Liberação e Imobilização-Exercitação $x$ Imobilização-Liberação, não mostrou diferença significativa (FIGURA 14).

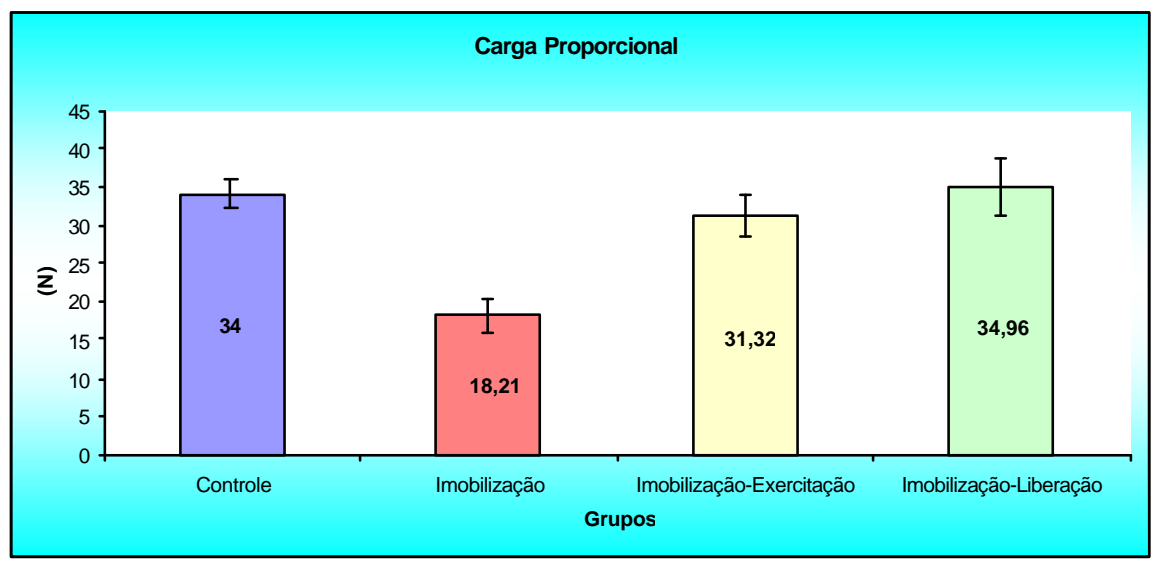

FIGURA 14 - Comparação entre os valores médios das cargas proporcionais nos diferentes grupos. 


\subsection{Deformação no limite de proporcionalidade}

O valor médio para a deformação proporcional foi $(12,19 \pm 2,10) 10^{-3} \mathrm{~m}$ para os músculos Controle, $(10,69 \pm 1,53) 10^{-3}$ para o grupo Imobilização, $(8,69 \pm 0,75) 10^{-3} \mathrm{~m}$ para o grupo Imobilização-Exercitação e $(12,75 \pm 2,39) \cdot 10^{-3} \mathrm{~m}$ para o grupo Imobilização-Liberação. A comparação entre os grupos Controle $x$ Imobilização-Exercitação e ImobilizaçãoExercitação $x$ Imobilização-Liberação mostrou que houve diferença significativa entre as médias com $\mathrm{p}<0,05$. A comparação entre os grupos Controle $x$ Imobilização, Controle $x$ Imobilização-Liberação, Imobilização $x$ Imobilização-Liberação $\mathrm{e}$ Imobilização $x$ Imobilização-Exercitação não mostrou diferença significativa (FIGURA 15).

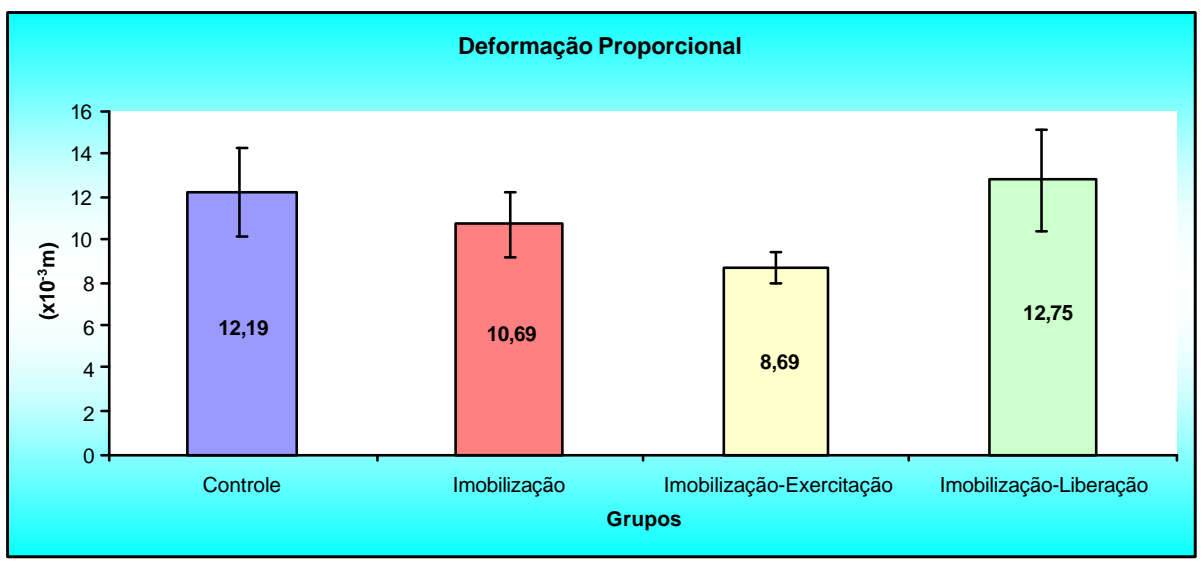

FIGURA 15 - Comparação entre os valores médios das deformações proporcionais nos diferentes grupos. 


\subsection{Resiliência}

O valor médio para a resiliência foi $(190,59 \pm 32,27) 10^{-3} \mathrm{~J}$ para os músculos Controle, $(96,52 \pm 22,89) 10^{-3} \mathbf{J}$ para o grupo Imobilização, $(131,75 \pm 22,86) 10^{-3} \mathbf{J}$ para o grupo Imobilização-Exercitação e $(203,99 \pm 30,12) 10^{-3} \mathrm{~J}$ para o grupo Imobilização-Liberação. A comparação entre os grupos mostrou que houve diferença significativa entre eles com p $<0,05$, com exceção de Controle $x$ Imobilização-Liberação e Imobilização-Exercitação $x$ Imobilização (FIGURA 16).

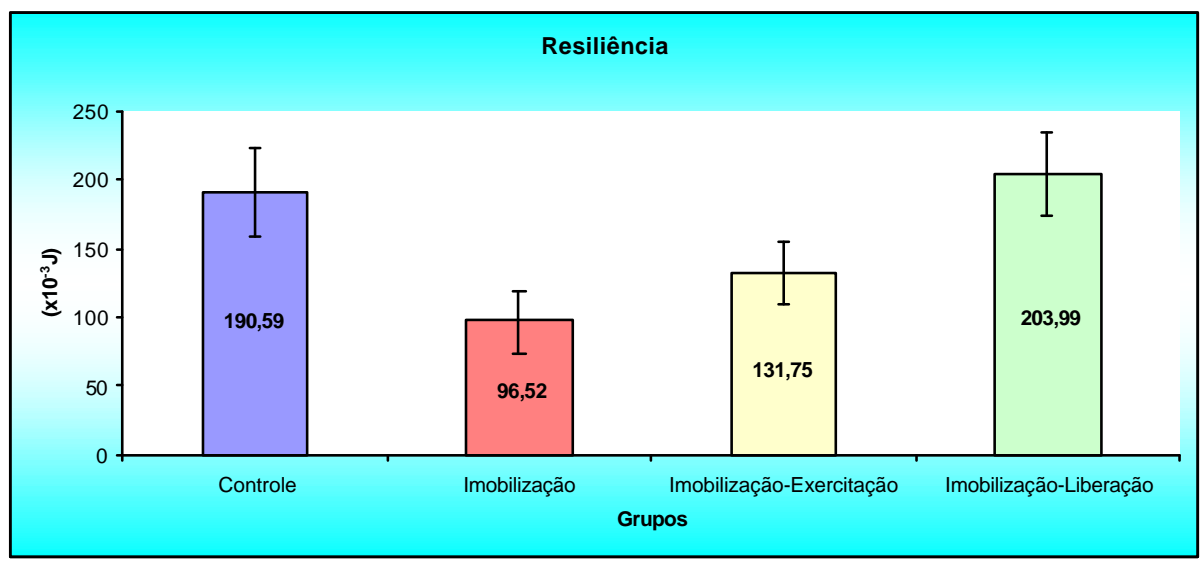

FIGURA 16 - Comparação entre os valores médios da resiliência e desvio padrão nos diferentes grupos. 


\subsection{Rigidez}

O valor médio para a rigidez foi $(3,09 \pm 0,41) 10^{3} \mathrm{~N} / \mathrm{m}$ para o grupo Controle, $(1,68 \pm 0,17) 10^{3} \mathrm{~N} / \mathrm{m}$ para o grupo Imobilização, $(3,47 \pm 0,18) 10^{3} \mathrm{~N} / \mathrm{m}$ para o grupo Imobilização-Exercitação e $(3,00 \pm 0,48) 10^{3} \mathrm{~N} / \mathrm{m}$ para o grupo Imobilização-Liberação. A comparação entre os grupos mostrou que houve diferença significativa entre eles com $\mathrm{p}<0,05$, com exceção de Controle $x$ Imobilização-Exercitação e Controle $x$ ImobilizaçãoLiberação (FIGURA 17).

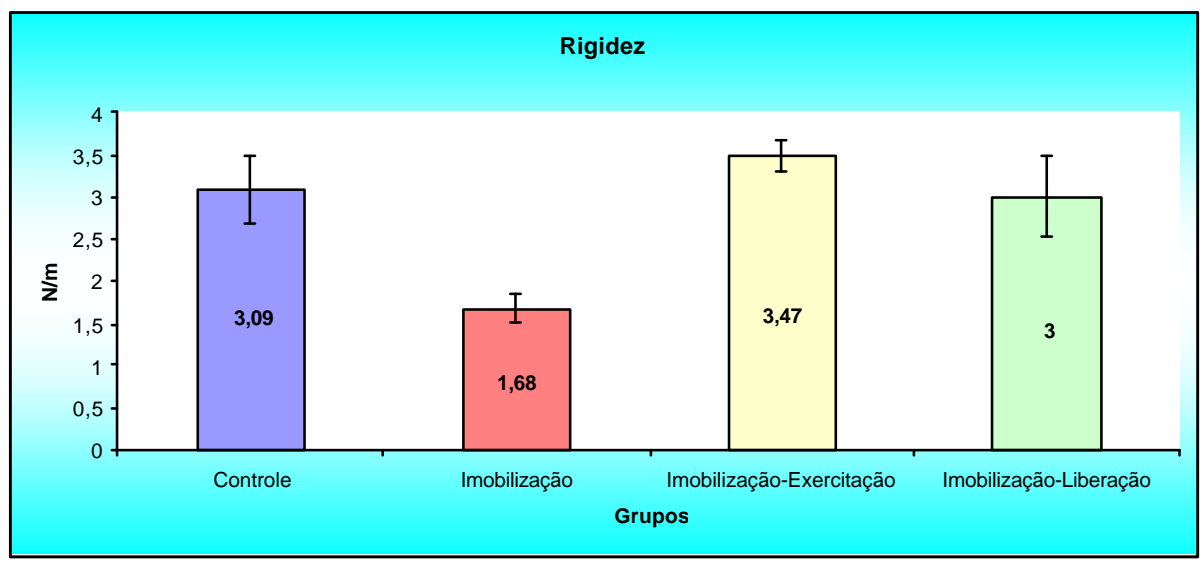

FIGURA 17 - Comparação entre os valores médios da rigidez e desvio padrão nos diferentes grupos. 
A FIGURA 18 ilustra as curvas representativas das médias para o limite de proporcionalidade e limite máximo dos ensaios de cada grupo.

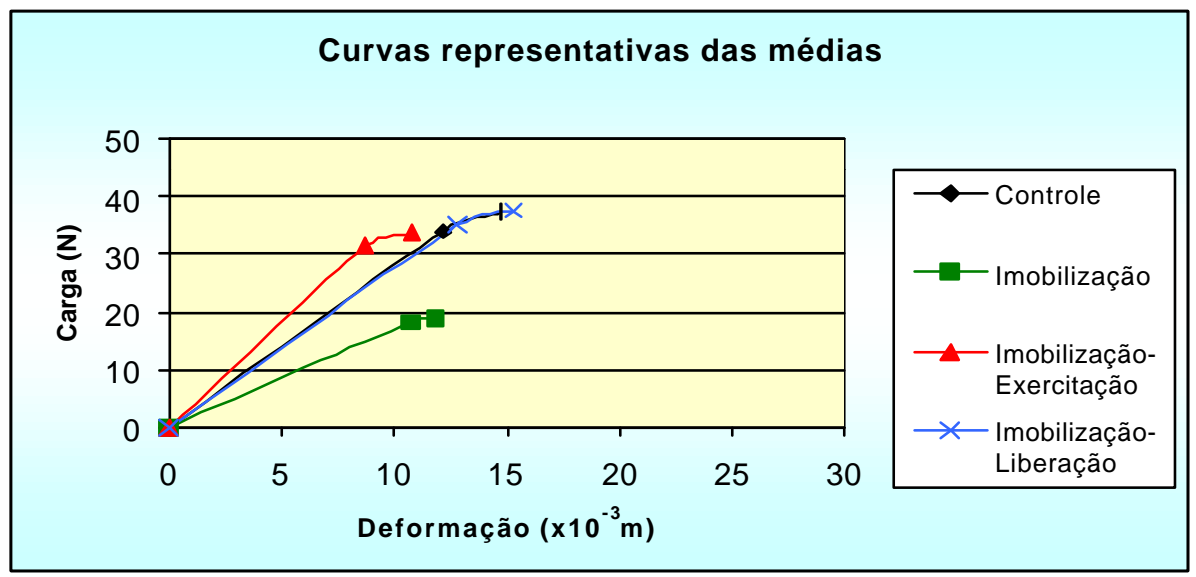

FIGURA 18 - Curvas representando as médias das propriedades mecânicas. O primeiro ponto mostra o limite de proporcionalidade e o segundo, o limite máximo para os diferentes grupos experimentais. 


\section{DISCUSSÃO}

A Mecânica estuda as forças que agem sobre um corpo. O estudo da biomecânica aplica os princípios da mecânica aos corpos humanos e animais. Os profissionais que trabalham com lesões do sistema músculo-esquelético precisam compreender como as forças controlam o movimento. De todas as ciências básicas, a Mecânica possui uma aplicação direta para a terapia de lesões e recuperação funcional de problemas músculo-esqueléticos. O conhecimento de princípios mecânicos é essencial para a compreensão do diagnóstico, tratamento e prevenção de lesões ortopédicas e esportivas (RADIN et al.,1979 apud GOULD, 1993).

Os materiais biológicos e os usados na engenharia são diferentes, porém os equipamentos utilizados nestas áreas sugerem estudos na interface. Algumas técnicas de análise utilizadas na Engenharia podem ser adaptadas aos estudos de materiais biológicos.

As propriedades dos materiais podem ser determinadas pela observação do comportamento de estruturas já existentes, porém a forma de maior confiabilidade é realizada por meio de ensaios padronizados, que proporcionam resultados comparáveis e reprodutíveis (SHIMANO \& SHIMANO, 2000). Estes ensaios são denominados ensaios mecânicos.

O melhor ensaio a ser realizado é aquele em que podemos simular principalmente a maior força solicitada em atividades normais. Os músculos são mais solicitados a esforços de tração. Portanto, os ensaios realizados foram os ensaios de tração.

Os efeitos da imobilização sobre os aspectos morfológicos, fisiológicos e bioquímicos do músculo esquelético têm sido amplamente estudados (THOMPSON, 1934; BOOTH \& KELSO, 1973; BOOTH, 1977; HERBISON et al.., 1978; FOURNIER et al.,

3 RADIN, E. et al. (1979). Practical biomechanics for the orthopaedic surgeon. New York, John Wiley \& Sons. 
1983; FITTS et al., 1986; APPELL, 1986a; MUSACCHIA et al.,1988; HESLINGA et al., 1992; KASPER et al., 1993; ANSVED, 1995; VANDENBORNE et al., 1998), bem como os efeitos da remobilização e exercício físico sobre os mesmos aspectos (COOPER, 1972; BOOTH, 1978; BOOTH \& SEIDER, 1979; MACDOUGALL et al., 1980; APPELL, 1986b; MAEDA et al., 1993; FITTS \& WIDRICK, 1996; VANDENBORNE et al., 1998; ZARZHEVSKY, 1999).

Por outro lado, poucos foram os trabalhos encontrados na literatura que enfatizavam em seus objetivos e conclusões, como se processa a recuperação da resistência do músculo após a imobilização e, imobilização seguida de exercitação (JÄRVINEN, 1976; JÄRVINEN,.1977; JÄRVINEN et al., 1992; KANNUS et al., 1992a; KANNUS et al., 1992b; JÄRVINEN, 1993).

Por esta razão, este trabalho objetivou investigar os efeitos da imobilização e remobilização em algumas propriedades mecânicas do músculo esquelético.

Para a realização dos ensaios mecânicos de tração não foram encontradas dificuldades em relação à metodologia, pois a equipe do Laboratório de Bioengenharia da FMRP - USP tem experiência com ensaios estáticos de materiais biológicos.

Antes da realização dos ensaios de tração definitivos deste trabalho, foram realizados testes piloto com o objetivo de padronizar os ensaios de forma global. Esta fase foi importante para a escolha dos acessórios para fixação do músculo na máquina universal de ensaios e para padronizar a velocidade de aplicação da carga e da pré-carga utilizadas nos ensaios. Estabelecemos a velocidade de $0,5 \mathrm{~mm} /$ minuto por ter sido a que melhor se adaptava ao material de estudo.

Os animais mais utilizados nos trabalhos consultados foram ratos da linhagem Sprague-Dawley e ratos albinos da linhagem Wistar. Neste trabalho utilizamos ratos da linhagem Wistar.

A imobilização por meio de aparelho de gesso é a mais utilizada nos modelos experimentais. Optamos pelo modelo proposto por BOOTH \& KELSO (1973), adaptado 
para somente um membro posterior do rato, mantendo imobilizados quadril e joelho. Segundo estes autores, o modelo é de grande aceitabilidade devido à ausência de ulcerações de pele, edema na pata ou formação de úlceras gástricas e, por produzir atrofia muscular, descartando as técnicas invasivas. Dois animais de nosso experimento morreram durante o período de imobilização. Não apresentaram lesões de pele ou alteração de comportamento antes da morte.

Uma modalidade experimental de exercícios para ratos freqüentemente utilizada, é a esteira rolante. Um estímulo elétrico é acoplado para assegurar o treinamento físico dos animais e os animais são treinados individualmente. Nesta pesquisa utilizamos a natação como modalidade de exercício, com comprovada solicitação física dos animais. A natação permite que um número significativo de animais seja treinado simultaneamente sob as mesmas condições experimentais. Não há necessidade de estímulos artificiais, como o choque elétrico para induzir o exercício físico (VIEIRA et al., 1988).

Inicialmente, tentamos desenvolver o sistema de natação proposto por VIEIRA et al. (1988) onde os ratos nadavam em tanques individuais construídos com tubos de PVC de $250 \mathrm{~mm}$ de diâmetro. Observamos que os ratos mantinham-se na superfície da água sem movimentar ou movimentando pouco os membros. Como nosso propósito era que os ratos se exercitassem mais, retiramos os tubos do tanque e mantivemos as condições de temperatura e agitação da água. Os animais movimentaram-se de maneira bastante satisfatória, sem intercorrências como afogamento, mesmo após 60 minutos ininterruptos de exercício.

Selecionamos o músculo gastrocnêmio para o estudo por sua localização e função. Geralmente este músculo trabalha sob condições de atividade física extrema, tendo risco aumentado para lesões ou rupturas e o tratamento requer períodos de imobilização (JÄRVINEN et al., 1992). Além disto, esse músculo apresenta a vantagem de poder ser ensaiado preservando-se a origem e inserção óssea o que facilita a fixação para o ensaio.

Usamos um grupo de animais especialmente como controle e não o membro contralateral. O membro contralateral foi utilizado como controle em quase todos os 
trabalhos consultados. Entretanto, HESLINGA et al. (1992) mostraram que o músculo contralateral não é totalmente adequado para avaliar os efeitos da imobilização, pois também sofre alterações na morfologia e propriedades funcionais quando o membro oposto é imobilizado.

Segundo WOO et al. (1982), tecidos biológicos com dimensões pequenas são de difícil fixação à máquina de ensaio devido ao escorregamento nos pontos de fixação. Os acessórios desenvolvidos para fixação do músculo na máquina, foram eficazes. A posição de fixação na máquina e a tração axial longitudinal respeitaram a orientação anatômica. $\mathrm{O}$ músculo foi mantido hidratado após a dissecação e durante o ensaio (JÄRVINEN, 1976).

$\mathrm{O}$ peso da peça obtida para o ensaio foi analisado, sendo que houve redução significativa $(\mathrm{p}<0,05)$ após três semanas de imobilização. O peso foi recuperado após a retirada da imobilização e período de remobilização, independentemente da exercitação ou liberação.

O diâmetro de ventre muscular pode ser utilizado como medida para análise do trofismo. Houve redução de $23 \%$ do diâmetro do músculo com a imobilização. Os dados estão de acordo com os reportados por APPELL (1986a), em uma revisão realizada sobre o assunto. Com a retirada da imobilização e o período de quatro semanas de remobilização, o trofismo foi recuperado, não havendo diferença estatisticamente significante entre os grupos.

A presença de atrofia muscular, aderências e diminuição da amplitude articular no membro imobilizado também foi observada por DOMINGOS (1998).

Nos músculos testados a ruptura ocorreu no ventre muscular em $81 \%$ dos casos. Observamos rompimento na origem muscular em $8 \%$ dos casos e, $11 \%$ romperam-se na inserção no osso calcâneo. JÄRVINEN (1976) em seu trabalho com ensaio de tração do músculo gastrocnêmio relatou que a ruptura ocorreu no ventre muscular em $94 \%$ dos casos. Neste local a quantidade de tecido muscular é maior que a de tecido conjuntivo., sendo o ponto mais fraco do músculo. Esse autor também associou os diferentes locais de ruptura à alterações musculares pré-existentes. Utilizamos o gráfico carga $x$ deformação para avaliação 
dos dados obtidos. O ideal seria a correlação com a tensão. Entretanto, a área de secção transversal necessária para o cálculo não poderia ser medida pois o ensaio do músculo foi destrutivo e a ruptura não acontece linearmente. Com esta limitação substituímos o cálculo do módulo de elasticidade pela rigidez. Este procedimento também foi adotado por JÄRVINEN (1977), em trabalho semelhante.

Analisando os parâmetros obtidos na fase plástica, constatamos que a carga máxima foi equivalente para os músculos controle, imobilização-exercitação e imobilizaçãoliberação, diminuindo em aproximadamente $50 \%$ para os músculos imobilizados. A deformação máxima para os músculos imobilizados foi semelhante aos valores obtidos para os exercitados. Estes resultados sugerem uma menor capacidade do músculo exercitado em alongar-se embora suportasse carga semelhante aos músculos controle. Segundo KANNUS et al. (1992a) , juntamente com as mudanças que ocorrem nas fibras musculares, o tecido conjuntivo também responde a um treinamento físico, aumentando a quantidade absoluta de tecido.

A fase elástica reflete uma etapa de deformação reversível, mais próxima do funcionamento do músculo em condições normais. Nesta fase a carga no limite de proporcionalidade foi reduzida significativamente para os músculos imobilizados em relação aos grupos Controle, Imobilização-Exercitação e Imobilização-Liberação, não sendo encontradas diferenças nas comparações entre os grupos Controle, Imobilização-Exercitação e Imobilização-Liberação. A deformação no mesmo limite não foi diferente nos músculos controle e imobilizados-liberados. Observamos que apesar do valor da deformação no limite de proporcionalidade ser $19 \%$ maior para os músculos imobilizados que os exercitados, a carga aplicada para a deformação sofrida nos músculos imobilizados foi $42 \%$ menor que a verificada para os músculos exercitados.

Houve redução significante na rigidez para os músculos imobilizados, ou seja, o músculo deformou mais, a uma carga menor. Estas alterações devem ser levadas em consideração no processo de reabilitação para evitar complicações ou sobrecarga muscular. 
A rigidez foi maior para os músculos que foram exercitados após a retirada da imobilização, provavelmente devido ao treinamento físico aplicado e aumento de tecido conjuntivo.

Os dados mostram que a remobilização, independentemente da aplicação de um exercício físico específico, devolveu ao músculo suas propriedades elásticas. Resultados semelhantes foram encontrados por JÄRVINEN (1977) e JÄRVINEN et al. (1992). Porém a liberação foi melhor que a exercitação dentro dos parâmetros estabelecidos para o estudo. $\mathrm{O}$ músculo recuperou suas propriedades mecânicas comportando-se de forma semelhante ao controle.

A energia absorvida na fase elástica ou resiliência foi maior no grupo controle e imobilização-liberação. Não houve diferença significativa na comparação entre os músculos imobilizados e imobilizados-exercitados. Acreditamos que a menor capacidade do músculo exercitado em absorver energia de deformação na fase elástica esteja relacionada à posição de imobilização do membro, onde o músculo foi mantido predominantemente em posição encurtada. Segundo JÄRVINEN et al. (1992) há um aumento na quantidade de tecido conjuntivo no músculo quando imobilizado em posição encurtada, o que poderia deixar o músculo menos elástico. Ao realizar o exercício de natação, o músculo gastrocnêmio também foi trabalhado em posição encurtada devido aos movimentos natatórios dos membros posteriores. Por outro lado, a habilidade dos músculos em absorver energia sem se romper é importante para a prevenção de lesões. Quando muita energia é absorvida, o material poderá romper-se, como ocorre em algumas distensões e fraturas (GOULD, 1993). Uma análise histológica provavelmente nos traria respostas mais objetivas.

Outro dado interessante observado foi que o desvio padrão nos valores médios obtidos para as propriedades mecânicas foi consideravelmente menor para os músculos exercitados comparados aos imobilizados-liberados. O mesmo aconteceu com os músculos imobilizados. Podemos inferir que uma demanda específica, em nosso caso a imobilização e o exercício de natação proporcionaram ao músculo um comportamento mais homogêneo, 
enquanto que os outros grupos mostraram maior variabilidade biológica em seu comportamento. 


\section{CONCLUSÕES}

1. A imobilização provocou reduções significativas nos valores das propriedades mecânicas do músculo estudado.

2. A remobilização constituída por exercitação produziu aumento na rigidez do músculo, porém não houve recuperação da resiliência.

3. A remobilização livre após período de imobilização devolveu ao músculo suas propriedades mecânicas. 


\section{ANEXOS}

I. Valores de carga e deformação lidos durante os ensaios de tração dos 37 músculos. 
Anexos 50

\begin{tabular}{|c|c|c|c|c|c|c|c|c|c|}
\hline \multicolumn{10}{|c|}{ Grupo controle } \\
\hline $\mathrm{d}(\mathrm{mm})$ & Rato 1 & Rato 2 & Rato 3 & Rato 4 & Rato 5 & Rato 6 & Rato 7 & Rato 8 & Rato 9 \\
\hline 0 & 0,785 & 1,177 & 1,079 & 1,373 & 0,883 & 0,883 & 0,491 & 1,472 & 1,668 \\
\hline 0,5 & 1,275 & 2,453 & 2,845 & 2,158 & 1,668 & 1,472 & 2,551 & 1,962 & 2,453 \\
\hline 1 & 2,060 & 3,139 & 3,532 & 2,845 & 2,354 & 2,158 & 4,022 & 2,453 & 3,630 \\
\hline 1,5 & 2,943 & 4,218 & 4,316 & 3,434 & 3,335 & 2,551 & 5,101 & 2,943 & 4,611 \\
\hline 2 & 3,532 & 5,297 & 5,199 & 3,924 & 4,415 & 3,335 & 6,377 & 3,630 & 5,886 \\
\hline 2,5 & 4,218 & 6,475 & 5,984 & 4,611 & 5,494 & 4,022 & 7,750 & 4,218 & 6,867 \\
\hline 3 & 5,101 & 8,044 & 6,671 & 5,297 & 5,886 & 4,807 & 9,418 & 4,905 & 8,339 \\
\hline 3,5 & 5,788 & 9,418 & 7,750 & 6,082 & 7,652 & 5,592 & 11,183 & 5,788 & 9,614 \\
\hline 4 & 6,965 & 10,889 & 8,927 & 6,867 & 8,927 & 6,671 & 12,851 & 6,769 & 10,987 \\
\hline 4,5 & 8,044 & 13,047 & 9,908 & 7,848 & 10,399 & 7,554 & 14,519 & 7,652 & 11,968 \\
\hline 5 & 8,927 & 14,911 & 11,183 & 8,829 & 11,674 & 8,731 & 16,481 & 8,829 & 13,440 \\
\hline 5,5 & 10,104 & 16,775 & 12,263 & 10,301 & 13,145 & 9,810 & 18,345 & 10,202 & 14,617 \\
\hline 6 & 10,693 & 19,031 & 13,734 & 11,576 & 14,911 & 11,380 & 20,307 & 11,576 & 16,088 \\
\hline 6,5 & 12,066 & 21,190 & 12,753 & 13,342 & 16,481 & 12,164 & 22,465 & 12,753 & 17,560 \\
\hline 7 & 13,047 & 23,152 & 9,123 & 14,421 & 18,247 & 13,734 & 24,525 & 14,225 & 19,424 \\
\hline 7,5 & 13,734 & 24,525 & 10,006 & 16,088 & 20,307 & 14,715 & 26,487 & 15,598 & 20,895 \\
\hline 8 & 15,598 & 26,487 & 11,576 & 17,658 & 22,269 & 16,579 & 28,645 & 16,775 & 22,955 \\
\hline 8,5 & 16,775 & 28,253 & 7,750 & 19,130 & 24,035 & 18,149 & 30,607 & 18,050 & 24,917 \\
\hline 9 & 18,345 & 30,215 & 9,221 & 21,092 & 25,997 & 20,209 & 32,667 & 19,228 & 26,879 \\
\hline 9,5 & 19,914 & 31,686 & 10,693 & 22,661 & 27,762 & 21,876 & 34,629 & 20,012 & 28,35 \\
\hline 10 & 20,699 & 33,158 & 12,263 & 24,623 & 29,528 & 23,936 & 35,807 & 21,288 & 29,528 \\
\hline 10,5 & 22,955 & 34,433 & 12,361 & 26,879 & 30,803 & 25,506 & 37,180 & 22,759 & 31,000 \\
\hline 11 & 25,016 & 35,414 & 13,734 & 28,645 & 31,981 & 27,370 & 37,474 & 24,035 & 32,275 \\
\hline 11,5 & 26,879 & 36,395 & 15,696 & 30,313 & 32,864 & 29,430 & 38,259 & 25,310 & 33,158 \\
\hline 12 & 29,038 & 37,376 & 16,775 & 32,177 & 33,060 & 30,803 & 38,651 & 26,193 & 33,943 \\
\hline 12,5 & 31,000 & 37,376 & 18,050 & 33,845 & 33,550 & 32,569 & 38,848 & 26,781 & 34,826 \\
\hline 13 & 32,864 & 37,867 & 19,228 & 35,316 & 33,845 & 33,354 & 38,946 & 27,860 & 35,316 \\
\hline 13,5 & 34,531 & 37,965 & 20,012 & 36,689 & 34,139 & 34,531 & 38,848 & 28,940 & 7,65 \\
\hline 14 & 36,199 & 38,063 & 18,050 & 37,376 & 34,139 & 35,610 & 38,357 & 30,215 & 7,848 \\
\hline 14,5 & 37,180 & 37,965 & 19,031 & 38,259 & 33,943 & 36,297 & 37,670 & 31,490 & 8,927 \\
\hline 15 & 38,063 & 37,965 & 20,209 & 38,848 & 33,746 & 36,788 & 36,395 & 33,060 & 10,301 \\
\hline 15,5 & 38,553 & 37,670 & 20,993 & 39,240 & 33,452 & 37,082 & 35,414 & 33,648 & 11,968 \\
\hline 16 & 39,240 & 37,572 & 21,778 & 39,338 & 33,060 & 36,984 & 34,139 & 34,924 & 13,440 \\
\hline 16,5 & 39,044 & 37,376 & 10,006 & 39,731 & 32,667 & 36,984 & 32,177 & 35,708 & 15,107 \\
\hline 17 & 19,130 & 37,082 & 9,712 & 39,632 & 32,079 & 36,493 & 30,411 & 34,237 & 16,383 \\
\hline 17,5 & 21,484 & 36,493 & 9,418 & 39,632 & 31,588 & 36,101 & 28,057 & 35,414 & 18,247 \\
\hline 18 & 23,054 & 36,101 & & 39,142 & 30,902 & 35,316 & 25,506 & 36,395 & 20,503 \\
\hline 18,5 & 24,623 & 35,316 & & 38,357 & 30,313 & 34,826 & & 37,376 & 22,465 \\
\hline 19 & 26,879 & 34,531 & & 37,474 & & 34,335 & & 38,259 & 24,329 \\
\hline 19,5 & 28,449 & & & 36,199 & & 33,256 & & 38,357 & 25,408 \\
\hline 20 & 30,019 & & & 34,924 & & 32,177 & & 38,651 & 21,974 \\
\hline 20,5 & 29,724 & & & 33,550 & & 29,822 & & 38,553 & 23,054 \\
\hline 21 & 28,449 & & & 32,177 & & & & 38,259 & $23,34 \varepsilon$ \\
\hline 21,5 & & & & 31,000 & & & & 37,867 & 24,917 \\
\hline 22 & & & & & & & & 37,376 & 26,095 \\
\hline 22,5 & & & & & & & & 36,788 & 26,781 \\
\hline 23 & & & & & & & & 36,297 & 27,370 \\
\hline 23,5 & & & & & & & & 35,218 & 28,547 \\
\hline 24 & & & & & & & & 33,943 & 28,253 \\
\hline 24,5 & & & & & & & & 32,765 & 29,038 \\
\hline 25 & & & & & & & & 31,392 & 16,677 \\
\hline 25,5 & & & & & & & & & 15,69 \\
\hline 26 & & & & & & & & & 15,59 \\
\hline 26,5 & & & & & & & & & 8,33 \\
\hline 27 & & & & & & & & & $\overline{7,06}$ \\
\hline
\end{tabular}


Anexos 51

\begin{tabular}{|c|c|c|c|c|c|c|c|c|c|c|}
\hline \multicolumn{11}{|c|}{ Grupo imobilização } \\
\hline $\mathrm{d}(\mathrm{mm})$ & Rato 1 & Rato 2 & Rato 3 & Rato 4 & Rato 5 & Rato 6 & Rato 7 & Rato 8 & Rato 9 & Rato 10 \\
\hline 0 & 0,981 & 0,981 & 0,981 & 0,981 & 0,981 & 0,981 & 0,981 & 0,981 & 1,275 & 0,981 \\
\hline 0,5 & 1,668 & 2,158 & 1,472 & 1,962 & 1,766 & 2,256 & 1,962 & 2,060 & 2,060 & 1,766 \\
\hline 1 & 2,256 & 2,354 & 2,943 & 2,354 & 2,158 & 3,041 & 2,551 & 2,845 & 2,256 & 2,060 \\
\hline 1,5 & 2,747 & 2,845 & 3,924 & 2,845 & 2,551 & 3,826 & 3,237 & 3,630 & 2,453 & 2,354 \\
\hline 2 & 3,237 & 3,237 & 5,101 & 3,434 & 3,041 & 4,709 & 3,728 & 4,120 & 3,139 & 2,845 \\
\hline 2,5 & 3,630 & 3,532 & 5,886 & 3,924 & 3,434 & 5,690 & 4,513 & 4,611 & 3,335 & 3,53 \\
\hline 3 & 4.611 & 4,316 & 6.671 & 4,513 & 3.728 & 6,867 & 5,297 & 5,690 & 4.022 & 4,022 \\
\hline 3,5 & 5,297 & 4,905 & 7,456 & 5,003 & 4,218 & 8,339 & 5,592 & 6,475 & 4,709 & 4,709 \\
\hline 4 & 5,886 & 5,396 & 8,240 & 5,690 & 4,611 & $\overline{9,614}$ & 6,180 & 7,259 & 5,494 & 5,396 \\
\hline 4,5 & 7,063 & 6,180 & 9,123 & 6,377 & 5,101 & 11,183 & 7,161 & 8,339 & 6,278 & 6,180 \\
\hline 5 & 7,848 & 6,965 & 10,399 & 7,161 & 5,592 & 12,753 & 7,652 & 9,516 & 7,161 & 7,063 \\
\hline 5,5 & 9,025 & 7,652 & 11,380 & 8,044 & 6,278 & 14,519 & 8,633 & 10,693 & 7,946 & 7,750 \\
\hline 6 & 10,006 & 8,535 & 12,557 & 9,025 & 7,063 & 16,187 & 9,320 & 11,380 & 9,123 & 8,633 \\
\hline 6,5 & 10,987 & 9,614 & 13,734 & 9,810 & 7,750 & 17,364 & 10,104 & 12,263 & 9,712 & 9,320 \\
\hline 7 & 12,263 & 10,693 & 14,813 & 10,693 & 8,535 & 18,737 & 10,595 & 12,753 & 10,791 & 10,006 \\
\hline 7,5 & 13,342 & 11,674 & 16,285 & 11,772 & 9,516 & 20,307 & 11,380 & 13,734 & 11,282 & 10,595 \\
\hline 8 & 14,028 & 12,851 & 17,168 & 12,851 & 10,497 & 21,386 & 12,164 & 14,323 & 12,263 & 11,380 \\
\hline 8,5 & 14,813 & 14,126 & 18,050 & 13,734 & 11,576 & 22,171 & 13,047 & 15,304 & 12,949 & 11,968 \\
\hline 9 & 15,500 & 15,206 & 19,228 & 14,715 & 12,655 & 21,974 & 13,636 & 16,187 & 14,126 & 12,557 \\
\hline 9,5 & 16,285 & 16,285 & 19,718 & 15,696 & 14,421 & 18,639 & 14,323 & 17,069 & 15,107 & 13,538 \\
\hline 10 & 17,266 & 17,069 & 20,012 & 16,579 & 14,813 & 17,266 & 14,813 & $\overline{17,658}$ & 16,285 & $\overline{14,519}$ \\
\hline 10,5 & 18,149 & 17,952 & 19,816 & 17,168 & 15,206 & 15,206 & 14,519 & 17,756 & 17,364 & 15,696 \\
\hline 11 & 18,541 & 18,737 & 19,522 & 17,266 & 15,206 & 12,851 & 8,535 & 17,462 & 18,247 & 17,069 \\
\hline 11,5 & 19,228 & 19,130 & 18,149 & 17,069 & 14,028 & 11,183 & 6,475 & 16,775 & 18,835 & 18,443 \\
\hline 12 & 19,522 & 19,130 & 16,481 & 15,794 & 12.753 & 9,810 & & 14,911 & 19.620 & 18,933 \\
\hline 12,5 & 19,522 & 18,835 & 14,028 & 12,459 & 11,772 & 7,358 & & 13,145 & 20,503 & 19,914 \\
\hline 13 & 19,130 & 18,050 & 10,104 & 9,614 & 11,478 & & & 10,301 & 21,190 & 20,307 \\
\hline 13,5 & 18,835 & 17,560 & 7,750 & 5,788 & 10,301 & & & 7,358 & 21,582 & 21,288 \\
\hline 14 & 17,952 & 16,775 & 5,396 & & 9,614 & & & 5,199 & 21,778 & 21,778 \\
\hline 14,5 & 16,677 & 15,794 & & & 7,358 & & & & 21,484 & 22,367 \\
\hline 15 & 15,107 & 14,421 & & & & & & & 20,503 & 22,465 \\
\hline 15,5 & 13,440 & 12,557 & & & & & & & 18,737 & 22,367 \\
\hline 16 & 11,380 & 10,791 & & & & & & & 16,579 & 21,680 \\
\hline 16,5 & 9,614 & 9,221 & & & & & & & 14,323 & 19,914 \\
\hline 17 & 7,848 & 7,848 & & & & & & & 11,772 & 17,266 \\
\hline 17,5 & & & & & & & & & 9,712 & 15,500 \\
\hline 18 & & & & & & & & & 6,769 & 14,323 \\
\hline 18,5 & & & & & & & & & 4,513 & 11,085 \\
\hline 19 & & & & & & & & & & 7,848 \\
\hline 19,5 & & & & & & & & & & 6,5727 \\
\hline
\end{tabular}


Anexos 52

\begin{tabular}{|c|c|c|c|c|c|c|c|c|c|}
\hline \multicolumn{10}{|c|}{ Grupo imobilização-liberação } \\
\hline $\mathrm{d}(\mathrm{mm})$ & Rato 1 & Rato 2 & Rato 3 & Rato 4 & Rato 5 & Rato 6 & Rato 7 & Rato 8 & Rato 9 \\
\hline 0 & 1,177 & 1,373 & 1,079 & 1,275 & 0,785 & 1,668 & 1,766 & 1,275 & 1,373 \\
\hline 0,5 & 1,962 & 3,041 & 2,551 & 3,041 & 1,766 & 2,158 & 2,943 & 2,060 & 2,453 \\
\hline 1 & 2,453 & 4,218 & 4,022 & 3,924 & 2,354 & 2,747 & 3,532 & 2,747 & 3,335 \\
\hline 1,5 & 3,139 & 5,297 & 5,101 & 5,199 & 2,747 & 3,434 & 4,415 & 3,532 & 4,316 \\
\hline 2 & 3,532 & 6,475 & 6,769 & 6,377 & 3,335 & 3,924 & 5,101 & 4,316 & 5,003 \\
\hline 2,5 & 3,728 & 8,044 & 8,240 & 7,750 & 4,022 & 4,709 & 6,377 & 5,199 & 6,27 \\
\hline 3 & 3,924 & 9,418 & 10,006 & 8,829 & 4,513 & 5,396 & 7,554 & 6,180 & 7,456 \\
\hline 3,5 & 4,316 & 10,889 & 11,576 & 10,104 & 5,396 & 6,475 & 8,829 & 6,867 & 9,025 \\
\hline 4 & 4,513 & 12,655 & 13,538 & 11,380 & 6,180 & 7,652 & 10,104 & 8,044 & 10,104 \\
\hline 4,5 & 5,297 & 14,519 & 15,304 & 12,851 & 7,063 & 8,927 & 11,576 & 9,516 & 11,380 \\
\hline 5 & 5,788 & 16,579 & 17,364 & 14,028 & 8,240 & 10,301 & 12,557 & 10,497 & 13,047 \\
\hline 5,5 & 6,278 & 18,737 & 19,424 & 14,911 & 9,516 & 11,674 & 13,342 & 11,674 & 15,009 \\
\hline 6 & 6,867 & 20,895 & 21,484 & 15,892 & 10,497 & 13,244 & 13,832 & 12,851 & 16,971 \\
\hline 6,5 & 7,848 & 23,544 & 23,446 & 18,149 & 11,968 & 14,715 & 14,813 & 14,225 & 18,737 \\
\hline 7 & 8,731 & 25,408 & 25,506 & 20,601 & 13,244 & 16,579 & 15,598 & 14,813 & 20,797 \\
\hline 7,5 & 9,614 & 27,762 & 27,370 & 23,152 & 14,617 & 18,443 & 16,579 & 15,990 & 22,171 \\
\hline 8 & 10,202 & 29,528 & 29,332 & 25,310 & 15,794 & 20,111 & 17,364 & 16,971 & 24,427 \\
\hline 8,5 & 10,693 & 31,490 & 30,902 & 27,762 & 16,971 & 22,269 & 18,443 & 18,247 & 26,193 \\
\hline 9 & 10,987 & 33,060 & 32,079 & 29,921 & 17,756 & 24,035 & 17,658 & 19,718 & 27,566 \\
\hline 9,5 & 12,655 & 34,727 & 33,452 & 31,981 & 18,443 & 25,997 & 16,088 & 21,190 & 28,057 \\
\hline 10 & 13,832 & 36,395 & 34,924 & 33,746 & 18,541 & 27,959 & 15,892 & 22,661 & 28,253 \\
\hline 10,5 & 15,304 & 37,474 & 35,708 & 35,807 & 19,326 & 29,822 & 15,990 & 24,133 & 30,019 \\
\hline 11 & 17,069 & 38,357 & 36,395 & $\overline{37,474}$ & 20,307 & 31,588 & $\overline{14,813}$ & 25,212 & 31,294 \\
\hline 11,5 & 18,443 & 39,338 & 36,984 & 39,044 & 21,582 & 33,060 & 14,715 & 26,291 & 32,962 \\
\hline 12 & 20,012 & 39,731 & 37,572 & 40,515 & 23,446 & 34,433 & 14,519 & 27,468 & 34,041 \\
\hline 12,5 & 21,876 & 40,025 & 37,670 & 41,791 & 24,917 & 35,610 & 14,126 & 28,155 & 35,022 \\
\hline 13 & 23,838 & 40,221 & 37,769 & 42,575 & 26,781 & 36,493 & 13,440 & 29,038 & 35,512 \\
\hline 13,5 & 24,917 & 40,025 & 37,769 & 43,360 & 27,860 & 37,278 & 13,342 & 29,921 & 35,807 \\
\hline 14 & 26,487 & 39,927 & 37,376 & 43,851 & 29,528 & 37,474 & & 30,411 & 35,414 \\
\hline 14,5 & 28,057 & 39,240 & 37,082 & 44,047 & 31,294 & 37,965 & & 30,607 & 35,316 \\
\hline 15 & 29,430 & 38,750 & 36,591 & 44,439 & 32,962 & 38,161 & & 30,803 & 34,041 \\
\hline 15,5 & 30,705 & 38,161 & 36,101 & 44,145 & 34,237 & 38,553 & & 30,705 & 33,746 \\
\hline 16 & 32,275 & 37,180 & 35,610 & 44,734 & 35,022 & 38,651 & & 30,705 & 33,452 \\
\hline 16,5 & 33,550 & 36,395 & 35,022 & 45,028 & 35,905 & 38,750 & & 30,313 & 32,471 \\
\hline 17 & 34,531 & 35,512 & 34,237 & 44,930 & 36,297 & 38,357 & & 30,117 & 31,490 \\
\hline 17,5 & 35,610 & 34,826 & 33,550 & 44,930 & 36,788 & 38,161 & & 28,253 & 30,019 \\
\hline 18 & 36,395 & 33,746 & 32,667 & 45,126 & 36,984 & 37,867 & & 27,664 & 28,253 \\
\hline 18,5 & 36,689 & & & 45,224 & 36,788 & 37,376 & & 25,702 & 26,291 \\
\hline 19 & 36,984 & & & 45,420 & 36,689 & 36,886 & & 24,035 & \\
\hline 19,5 & 35,905 & & & 20,895 & 36,297 & 36,395 & & 21,484 & \\
\hline 20 & 35,708 & & & & 36,199 & 36,101 & & 19,130 & \\
\hline 20,5 & 35,120 & & & & 36,003 & 34,924 & & & \\
\hline 21 & 34,433 & & & & 35,610 & 33,746 & & & \\
\hline 21,5 & 33,845 & & & & 35,414 & 32,962 & & & \\
\hline 22 & 33,354 & & & & 35,218 & & & & \\
\hline 22,5 & 32,765 & & & & 34,629 & & & & \\
\hline 23 & 32,079 & & & & 34,041 & & & & \\
\hline 23,5 & 31,098 & & & & & & & & \\
\hline 24 & 29,822 & & & & & & & & \\
\hline
\end{tabular}


Anexos 53

\begin{tabular}{|c|c|c|c|c|c|c|c|c|c|}
\hline \multicolumn{10}{|c|}{ Ğrupo imobilização-exercitação } \\
\hline $\mathrm{d}(\mathrm{mm})$ & Rato 1 & Rato2 & Rato3 & Rato 4 & Rato 5 & Rato 6 & Rato 7 & Rato 8 & Rato 9 \\
\hline 0 & 0,981 & 0,785 & 1,177 & 0,981 & 1,177 & 1,275 & 1,570 & 0,687 & 1,57 \\
\hline 0,5 & 2,845 & 2,354 & 3,434 & 3,041 & 3,434 & 2,453 & 2,747 & 2,354 & 2,845 \\
\hline 1 & 4,513 & 3,237 & 4,709 & 4,807 & 5,396 & 3,924 & 3,924 & 4,022 & 4,12 \\
\hline 1,5 & 6,377 & 4,120 & 6,180 & 6,475 & 7,554 & 5,886 & 6,769 & 5,101 & 5,69 \\
\hline 2 & 7,946 & 5,003 & 7,456 & 7,946 & 9,810 & 7,750 & 8,240 & 7,161 & 7,16 \\
\hline 2,5 & 9,712 & 5,690 & 8,829 & 9,418 & 11,870 & 9,908 & 9,908 & 8,437 & 8,633 \\
\hline 3 & 11,772 & 6,671 & 10,693 & 10,987 & 13,832 & 11,870 & 11,772 & 10,399 & 10,497 \\
\hline 3,5 & 13,636 & 8,142 & 12,263 & 12,851 & 15,696 & 14,323 & 13,636 & 12,361 & 12,557 \\
\hline 4 & 15,402 & 9,320 & 13,832 & 14,617 & 17,658 & 16,285 & 15,892 & 14,323 & 14,421 \\
\hline 4,5 & 17,266 & 10,791 & 15,696 & 16,481 & 19,326 & 18,639 & 17,364 & 16,383 & 16,383 \\
\hline 5 & 19,031 & 12,459 & 17,364 & 18,345 & 21,092 & 20,993 & 17,854 & 18,639 & 18,541 \\
\hline 5,5 & 20,699 & 14,126 & 19,130 & 20,111 & 22,563 & 22,955 & 19,620 & 20,993 & 20,699 \\
\hline 6 & 22,171 & 15,892 & 20,895 & 22,073 & 23,740 & 24,623 & 21,288 & 23,152 & 22,759 \\
\hline 6,5 & 23,642 & 17,952 & 23,250 & 23,642 & 25,506 & 26,683 & 23,054 & 24,525 & 24,91 \\
\hline 7 & 25,016 & 20,111 & 25,016 & 25,408 & 27,370 & 28,253 & 25,016 & 26,879 & 26,68 \\
\hline 7,5 & 26,193 & 21,778 & 26,487 & 27,174 & 28,743 & 30,313 & 26,781 & 29,234 & 29,038 \\
\hline 8 & 27,272 & 24,035 & 28,155 & 28,940 & 29,234 & 31,098 & 28,253 & 31,294 & 30,411 \\
\hline 8,5 & 28,547 & 25,997 & 29,724 & 30,607 & 30,117 & 32,177 & 29,921 & 33,158 & 31,68 \\
\hline 9 & 29,136 & 27,370 & 31,196 & 31,686 & 30,607 & 32,765 & 31,098 & 34,727 & 32,76 \\
\hline 9,5 & 29,822 & 29,234 & 32,275 & 32,962 & 30,902 & 33,060 & 31,981 & 36,199 & 33,648 \\
\hline 10 & 30,411 & 30,803 & 33,256 & 33,648 & 31,196 & 33,256 & 32,079 & 36,886 & 34,139 \\
\hline 10,5 & 30,705 & 32,079 & 33,746 & 34,139 & 30,705 & 33,158 & 32,275 & 37,769 & 34,335 \\
\hline 11 & 30,705 & 33,354 & 33,943 & 34,629 & 30,509 & 32,373 & 31,490 & 38,357 & 33,35 \\
\hline 11,5 & 30,509 & 33,845 & 34,139 & 34,924 & 30,117 & 31,196 & 30,803 & 38,259 & 32,667 \\
\hline 12 & 30,313 & 34,237 & 34,433 & 35,022 & 29,724 & 30,117 & 29,724 & 38,357 & 32,569 \\
\hline 12,5 & 30,019 & 34,433 & 34,237 & 34,924 & 29,136 & 28,645 & 27,762 & 38,455 & 31,88 \\
\hline 13 & 29,430 & 34,335 & 33,060 & 34,335 & 28,547 & 27,076 & 25,997 & 38,063 & 31,196 \\
\hline 13,5 & 29,136 & 33,845 & 32,373 & 33,943 & 27,272 & 24,721 & 23,446 & 37,474 & 30,705 \\
\hline 14 & 27,959 & 33,354 & 31,098 & 32,667 & 25,310 & 21,288 & 20,993 & 36,689 & 29,52 \\
\hline 14,5 & 26,585 & 32,569 & 29,430 & 31,784 & 22,563 & 18,050 & 18,050 & 35,905 & 28,743 \\
\hline 15 & 25,016 & 31,981 & 27,468 & 30,313 & 19,031 & 15,696 & 15,500 & 35,218 & 27,174 \\
\hline 15,5 & 23,446 & 30,411 & 25,016 & 28,743 & & & 13,047 & 34,139 & 25,016 \\
\hline 16 & & 29,430 & 22,269 & 27,174 & & & & 32,471 & \\
\hline 16,5 & & 27,174 & 20,307 & 25,212 & & & & 30,509 & \\
\hline 17 & & 24,623 & 18,247 & 20,895 & & & & 27,468 & \\
\hline 17,5 & & 20,895 & & & & & & 24,623 & \\
\hline
\end{tabular}




\section{REFERÊNCIAS BIBLIOGRÁFICAS}

ANSVED, T (1995). Effects of immobilization on the rat soleus muscle in relation to age. Acta Physiol Scand, v.154, p.279-290.

APPELL,H.J. (1986a). Skeletal muscle atrophy during immobilization. Int J Sports Med, v.7, n.1, p.01-05, Feb.

APPELL,H.J. (1986b). Morphology of immobilized skeletal muscle and the effects of a preand postimmobilization training program. Int J Sports Med, v.7, p.06-12.

APPELL, H.J. (1990). Muscular atrophy following immobilization. A review. Sports Med, v.10, n.1, p.42-58.

BINKLEY, J.M.; MALCOLM, P. (1986). The effects of immobilization on the properties of the ultrastructure and mechanical properties of the medial collateral ligament of rats. Clin Orthop Rel Res, n.203, p.301-308, Feb.

BOOTHF.W. (1977). Time course of muscular atrophy during immobilization of hindlimbs in rats. J Appl Physiol, v.43, p.656-661.

BOOTH, F.W. (1978). Regrowth of atrophied skeletal muscle in adult rats after ending immobilization. J Appl Physiol, v.44, n.2, p.225-230, Feb.

BOOTH,F.W.; KELSO,J.R. (1973). Protection of rat muscle atrophy by cast fixation. $J$ Appl Physiol, v.34, n.3, p.404 406, March. 
BOOTH,F.W.; SEIDER,M.J. (1979). Recovery of skeletal muscle after 3 mo of hindlimb immobilization in rats. J Appl Physiol, v.47, p.435- 439.

CARAZZATO, J.G.; BARROS Fo, T.E.P.; CAMARGO, O.P.; PÉCORA, J.R.; OLIVI, R.; SILVA, J.S. (1985). Estudo experimental da resistência muscular em condições normais e sob fadiga. Rev Bras Ortop, v.20, n.3, p.103-105.

CARAZZATO, J.G.; CAMARGO, O.P.; BARROS F', T.E.P.; RODRIGUES, C.J. (1980). Estudo experimental das alterações histológicas e biomecânicas induzidas pela infiltração local de corticóide e anestésico. Rev Bras Ortop, v.15, n.2, p.61-65.

CHIAVERINI, V. (1977). Tecnologia mecânica vol.1. São Paulo, Mc Graw-Hill do Brasil, p.67-88.

COOPER,R.R. (1972). Alterations during immobilization and regeneration of skeletal muscle in cats. J Bone Joint Surg, v.54 (A), n.5, p.919- 953, Jul.

DOMINGOS, C.S.P. (1998). Estudo da resistência mecânica do ligamento cruzado anterior de ratos submetidos à imobilização. São Carlos. 70p. Dissertação (Mestrado) Interunidades Bioengenharia - Escola de Engenharia de São Carlos, Faculdade de Medicina de Ribeirão Preto, Instituto de Química de São Carlos. Universidade de São Paulo.

FITTS,R.H.; METZGER,J.M.; RILEY,D.A.; UNSWORTH,B.R. (1986). Models of disuse: A comparasion of hindlimb suspension and immobilization. J Appl Physiol, v.60, n.3, p.1946-1953. 
FITTS,R.H.; WIDRICK,J.J. (1996). Muscle mechanics: adaptations with exercise- training. Exerc Sports Sci Rev, v.24, p.427-473.

FOURNIER,M.; ROY,R.R.; PERHAM,H.; SIMARD,C.P.; EDGERTON,V.R. (1983). Is limb immobilization a model of muscle disuse? Exp Neurol, v.80, p.147-156.

GARRET JR,W.E.; SAFRAN, M.R.; SEABER, A.V.; GLISSON, R.R.; RIBBECK, B.M. (1987). Biomechanical comparison of stimulated and nonstimulated skeletal muscle pulled to failure. Am J Sports Med, v.15, n.5, p.448-454.

GOULD III, J.A. (1993). Biomecânica básica na terapia esportiva e ortopédica. In: Fisioterapia na ortopedia e na medicina do esporte. São Paulo, Manole, p.65-83.

HARRELSON, G.L. (1998). Physiologic factors of rehabilitation. In: ANDREWS, J.R., HARRELSON, G.L., WILK, K.E., Physical rehabilitation of the injured athlete. Philadelphia, W.B.Saunders Company, p.13-37.

HERBISON, G.J.; JAWEED, J.F.; DITUNNO, J.F. (1978). Muscle fiber atrophy after cast immobilization in the rat. Arch Phys Med Rehabil, v.59, p.301-305, Jul.

HESLINGA,J.W.; ROZENDAL,R.H.; HUIJING,P.A. (1992). Unilateral immobilization affects contralateral rat gastrocnemius muscle architecture. Acta Anat, v.143, p.231- 235.

JÄRVINEN, M.(1976). Healing of a crush injury in rat striated muscle. Acta Chir Scand, v. 142, p.47-56. 
JÄRVINEN, M. (1977). Immobilization effect on the tensile properties of striated muscle: an experimental study in the rat. Arch Phys Med Rehabil, v. 58, p. 123- 127.

JÄRVINEN, M.; EINOLA, S.A.; VIRTANEN, E.O. (1992). Effect of the position of immobilization upon the tensile properties of the rat gastrocnemius muscle. Arch Phisys Med Rehabil, v.73, n.3, p. 253-257, Mar.

JÄRVINEN, M.J. (1993). The effects of early mobilization and immobilization on the healing process following muscle injuries. Sports Med, v.15, n.2, p.78-89, Feb.

JUNQUEIRA, J.C.; CARNEIRO, J. (1999). Histologia Básica. Rio de Janeiro, Guanabara Koogan, p.159-178: Tecido muscular.

KANNUS, P.; JOZSA, L.; RENSTRÖM, P.; JÄRVINEN, M.; KVIST, M.; LEHTO, M.; OJA, P.; VUORI, I. (1992a). The effects of training, immobilization and remobilization on musculoskeletal tissue. 1. Training and immobilization. Scand J Med Sci Sports, v.2, p.100-118.

KANNUS, P.; JOZSA, L.; RENSTRÖM, P.; JÄRVINEN, M.; KVIST, M.; LEHTO, M.; OJA, P.; VUORI, I. (1992b). The effects of training, immobilization and remobilization on musculoskeletal tissue. 2. Remobilization and prevention of immobilization atrophy. Scand J Med Sci Sports, v.2, p.164-176.

KANNUS,P.; JOZSA,L.; JÄRVINEN,T.L.N.; KVIST,M.; VIENO,T.; JÄRVINENT.H.A.; NATRI,A.; JÄRVINEN,M. (1998). Free mobilization and low- to high-intensity exercise in immobilization- induced muscle atrophy. J Appl Physiol, v.84, n.4, p.1418-1424. 
KANNUS,P.; JÓZSA,L.; NATRI,A.; JÄRVINEN,M. (1997). Effects of training, immobilization and remobilization on tendons. Scand J Med Sci Sports, v.7, n.2, p.67-71.

KASPER,E.C.; MCNULTY,A.L.; OTTO,A.J.; THOMAS,D.P. (1993). Alterations in skeletal muscle related to impaired physical mobility: an empirical model. Res Nurs Health, v.16, p.265-273.

LIEBER, R.L. (1992). Skeletal muscle sructure and function. Implications for rehabilitation and sports medicine. Baltimore, Willians \& Wilkins. Cap.5, p.210-259: Skeletal muscle adaptation to decreased use.

LIEBER, R.L.; MCKEE-WOODBURN, T.; FRIDEN, J.; GERSHUNI, D.H. (1989). Recovery of the dog quadriceps after tem weeks of immobilization followed by four weeks of remobilization. J Orthop Res, v.7, p.408-412.

MACDOUGALL,J.D.; ELDER,G.C.D.; SALE,D.G.; MOROZ,J.R.; SUTTON,J.R. (1980). Effects of strength training and immobilization on human muscle fibres. Eur J Appl Physiol, v.43, p.25-34.

MACMASTER,P.E.(1933) Tendon and muscle ruptures. J Bone Joint Surg, v.15, p.705-722.

MAEDA,H.; KIMMEL,D.B.; RAAB,D.M.; LANE,N.E. (1993). Musculoskeletal recovery following hindlimb immobilization in adult female rats. Bone, v.14, p.153-159.

MENEZES, D.F.; VOLPON, J.B.; SHIMANO, A.C. (1999). Aplicação de ultra-som terapêutico em lesão muscular experimental aguda. Rev Bras Fisiot, v.4, n.1, p.27-31. 
MÜLLER, S.S. (1998). Análise comparativa das propriedades mecânicas do ligamento da patela e do tendão calcâneo. Estudo experimental em cadáveres humanos. Botucatu. 231p. Tese (Doutorado) - Faculdade de Medicina de Botucatu, Universidade Estadual Paulista.

MUSACCHIA.X.J.; STEFEN,J.M.; FELL,R.D. (1988). Disuse atrophy of skeletal muscle: animal models. Exerc Sport Sci Rev, v.16, p.61-87.

RAMOS, R.S. (1979) Biomecânica. Conceito atual. Rev Bras Ortop, v.14, n.4, p.141-143.

ROSE, S.J.; ROTHSTEIN, J.M. (1982). Muscle biology and physical therapy. Phys Ther, v.62, p.1754-1756.

ROSSI, J.D.M.B.A.; LEIVAS, T.P.; MORÉ, A.D.O.; CAMANHO, G.L.; MONTENEGRO, N.B.; MACHADO, J.W.R. (1990). Ligamento cruzado anterior e tendão patelar: estudo mecânico e correlações clínicas. Rev Bras Ortop, v.25, n.6, p.197-201.

SALOMÃO, O.; FERNANDES, T.D.; CARVALHO JR, A.E.; LEIVAS, T.P.; TRANCHITELLA, F.B.; NARDELLI, J.C.C.; FILHO, J.H.A.; KOKRON, A.E.V. (1994). Avaliação das propriedades mecânicas do tendão do músculo tibial posterior submetido a ensaio de tração axial. Rev Bras Ortop, v.29, n.7, p.483-486.

SALVINI, T.F. (2000). Plasticidade e adaptação postural dos músculos esqueléticos. In: MARQUES, A.P. Cadeias musculares. Um programa para ensinar avaliação fisioterapêutica global. São Paulo, Manole. Introdução, p.3-14. 
SELL, S.; SCHULZ, R.; BALENTSIEFEN, M.; WEBER, H.; KÜSSWETTER, W. (1996). Lesions of the Achilles tendon. A sonographic, biomechanical and histological study. Arch Orthop Trauma Surg, v.115, p.28-32.

SHIMANO, A.C.; SHIMANO, M.M. (2000). Ensaios tecnológicos de materiais biológicos. In: CONGRESSO BRASILEIRO DE ENGENHARIA BIOMÉDICA. Florianópolis, 2000. Anais. Santa Catarina, CEBEB. v.1, p. 15-21.

SILVEIRA, M.I.A.; PÉROT, C.; GOUBEL, F. (1994). Plasticidade muscular. CCS, v.13, n.3, p.23-32, jul-set.

SOUZA, S.A. (1974). Ensaios mecânicos de materiais metálicos. São Paulo, Edgard Blücher, p.3-58: Ensaio de tração.

TAYLOR, D.C.; DALTON JR, J.D.; SEABER, A.V.; GARRET JR, W.E. (1990). Viscoelastic properties of muscle-tendon units. The biomechanical effects of stretching. Am J Sports Med, v.18, n.3, p.300-309.

THOMPSON, C. (1934). Experimental muscular atrophy. J Bone Joint Surg, v.16, p.564-571, Jul.

VANDENBORNE,K.; $\quad$ ELLIOTT,M.A.; $\quad$ WALTER,G.A.; $\quad$ ABDUS,S.; OKEREKE,E; SHAFFER, M.; TAHERNIA,D.; ESTERHAI,J.L. (1998). Longitudinal study of skeletal muscle adaptations during immobilization and rehabilitation. Muscle Nerve, v.21, p.10061012. 
VIEIRA,R.; HAEBISCH,H.; KOKUBUN,E.; HELL,N.S.; CURI,R. (1988). Swimming system for physical exercise of rats. Arq Biol Tecnol, v.31, n.3, p387-394, Ago.

WOO,S.L-Y.; GOMEZ,M.A.; WOO,Y-K.;AKESON,W.H. (1982). Mechanical properties of tendons and ligaments II. The relationships of immobilization and exercise on tissue remodeling. Biorheology, v.19, p.397-408.

ZARZHEVSKY,N.; COLEMAN,R.; VOLPIN,G,; FUCHS,D.; STEIN,H.; REZNICK,A.Z. (1999). Muscle recovery after immobilization by external fixation. J Bone Joint Surg, v.81-B, p.896-901. 